\title{
CHURCH AND STATE IN THE COSMOS OF CRETE
}

I

Here begins a presentation of the evidence for the complexity of the great pre-Greek civilization, focused in Crete and bearing, from the dynasty of the Priest-King called Minos or the Minos, the name of Minoan. This Aegean civilization gave many gifts to the coming Greeks - to those who, using Minoan script to write proto-Greek, as Ventris and Chadwick have shown, established the Homeric civilization of Mycenae, and to those who, surviving the onslaught of the Dorian Greeks, finally established the comprehensive civilization of classical times. In this classical civilization even the initially destructive Dorians played a constructive part, but it was in the little land most influenced by the Minoan heritage, Attica, that Greece most characteristically became the Greece still transmitting to the rest of the world the remoter effects, at least, of the great epoch of the Priest-King. What will here be recounted is only a prelude, limited to the days before the Palace of the Minos was given to the flames, and may later be followed by themes developing the events of the Greek world proper; nevertheless, even a prelude may have a profound bearing on the coming symphony.

II

Not for the Dorians the "wooden walls" of the peoples of the ships, nor any walls at all, so long, and only so long, as they held a temper like their blades of the good gray iron. Hard, unbending, their speech direct as a spear-thrust, the onset of their deep-serried line like the cleaving cut of a broadsword, these Dorians it was of whom Hesiod, scion of a defeated stock, spoke his bitter words: "Their righteousness in their fists!" 1

But who were those half-legendary, half-real men of bronze who lived in the Aegean lands before the coming of the ironwielding cattle-raiders of the north? Hesiod has no bitter words for them, none

1 Hesiod, Works and Days, 156 et seq. 
of the venom of impotent hatred; he speaks with deep emotion of their passing: "Evil war and awful battle slew them all". 1

Many are the stories: of Jason's Argonauts and the fearful revenge of Medea, of the siege of Troy and the fall of ash-speared Priam's folk, of the wanderings of the returning heroes and the bloody aftermaths of their homecomings - all these we know. They mark the breakup of the age of bronze, but the iron has not yet struck. Cherished gauds and trinkets, and sometimes an uncanny tool or weapon, give warrant for the saying, "Iron doth of itself draw a man on" 2, but the strange gray metal is not yet a common thing. ${ }^{3}$ The earlier Homeric Epic, and all that surrounds it, is still a tale of the struggles of the men of bronze against each other, not against the men of iron. The chilled edges have yet to slash through bronze helms and corselets, to pierce

1 Ibid.

2 Od. xvi, 294; xix, 13 .

3 "Gray" iron, od. ix, 393; "flaming" iron, od. i, r84; iron axes, Il. xxiii, 850; "selfsmelted" or "self-poured" - i.e., probably meteoric iron (but see John L. Myres, Who Were the Greeks?, Vol. VI: Sather Classical Lectures [Berkeley: The University of California Press, I 930], p. 442, and J. A. Rickard, "The Primitive Smelting of Iron", American Journal of Archeology, XLIII, No. I [January-March, 1939], pp. 85-86); Il .xxiii, 826; iron knife, Il. xviii, 34; iron mace or club - wielded by a hero whose skill with this most unusual weapon brought him fame, Il. vii, I4I; iron etters, Od. i, 204; iron gates - of the nether world, and hence perhaps not thought of as an ordinary metal, Il. vii, I5; iron chariot axle - of the goddess Hera, hence probably "precious" iron, Il. v, 623.

Iron is mentioned, counting adjectival and compound forms (Alban Dawes Winspear, The Genesis of Plato's Thought [New York: The Dryden Press, Inc., 1940], p. 313, note Io), 22 times in the Iliad, 25 in the Odyssey. This leads Winspear to say, "Iron is mentioned slightly more often in the Odyssey than in the Iliad" (The Genesis of Plato's Thought, p. 20). This is correct enough, but what Winspear fails to take full account of is the proportional mention; on this basis iron is mentioned four times as often in the Odyssey. Let us give these proportions: in the Iliad and Odyssey combined, iron accounts for almost 9 per cent of the references; in the Iliad alone, slightly more than 5 per cent; in the Odyssey alone, a trifle more than 20 per cent.

Note, now, that even if one were disposed to grant Myres' contention (Who Were the Greeks?, p. 435), that from bronze to iron "the transition is now known to have been gradual, and to have been more rapid in some districts than in others" - and the present writer is certainly disposed to grant it, for "ages" do not start on schedule - it is still true that the Iliad, generally acknowledged to be the earlier part of the Homeric Epic (see end of note 5), grants little place to iron except as a rate or even precious metal. Bronze is mentioned almost twenty times as often. Cf. Fritz Taeger, Das Altertum (4th ed.; Stuttgart: W. Kohlhammer, 1950), p. I 2 .

For further discussions of iron in Homer, see Martin P. Milsson, Homer and Mycenae (London: Methuen and Co., Ltd. 1933), p. 139 and the articles and books he cites in footnote 5; Arnold J. Toynbee, A Study of History (2nd ed.; London: Humphrey Milford, I935), III, p. 16r; A. R. Burn, Minoans, Philistines and Greeks (New York: Alfred A. Knopf, 1930), pp. 226-27; Robin Léon, Greek Thought and the Origins of the Scientific Spirit (New York: Alfred A. Knopf, I928), p. 75 and footnote I; E. C. Semple, The Geography of the Mediterranean Region (New York: Henry Holt and Co., I93I), pp. 684-85. 
the shields of sevenfold bullhide. ${ }^{1}$ When Patroclus and Hector fall clashing in the dust, it is bronze that lays them low. ${ }^{2}$

Hesiod uncertainly sets the age of heroes as a kind of strange interlude between the age of bronze and the age of iron $;^{3}$ he dimly realizes that there were times of sudden change from which stem his woes. Today we know, as Hesiod did not, that those times mark the end of the age of bronze and of the age of heroes alike. And yet Hesiod may have heard, perhaps from the bards of the Homeric Epic, that long before the speakers of the Greek tongue had made their way throughout the narrow seas there were other men of bronze on ship and shore. In the days of the elder gods, ere the heroes contended, Minos of Crete ruled "the wet ways".

Whatever Homer knew or Hesiod heard in ancient times, the Jast seventy-five years have revealed to us the wonders of that remoter age; 4 wielders of Cretan bronze were the mighty lords of great palaces at which the first marauding "Aryans" could only gape. Later

The arguments of Myres (Who Were the Greeks?, pp. 426-45) are interesting, but in spite of the great weight of his authority, not convincing to the present writer. His failure to convince lies in his assumption that the Homeric Epic deals with the coming of the Dorians as well as with the raids of the Achaeans and their contemporaries, and the whole weight of evidence goes to show that the Dorians play an altogether minor role, if any at all, in the Epic. (See J. D. S. Pendlebury, The Archeology of Crete [London: Methuen and Co., Ltd., I939], p. 260 and note 4). But see Myres, loc. cit., and the copious notes, pp. 582-95.

Incidentally, it should perhaps be mentioned here that reference to "Homer", "the Homeric Epic", etc., does not yet commit the present writer to a definite position with regard to the much-belabored "Homeric question". Such a position will eventually have to be taken, though with much reluctance and even diffidence, and at any rate not in this article.

2 Il. xvi, $761,803,819,821,862$; xxii, 225, 275, 328, 367. Iron is not referred to at all. 3 Myres, op. cit., pp. 426-45, 582-95. The collection of evidence is very full, and Myres' judgment carries great weight, but nevertheless his inferences are sometimes hard to follow. The reader is asked to take account of the notes above.

4 Here the great names of Near-Eastern and southwest European archeology appear: Schliemann, Dörpfeld, Wace, Müller, Karo, Evans, Mackenzie, Hawes, Blegen, Chapoutier, Roussel, Frödin, Persson, Hall, Matz, and others have added a whole new dimension to our knowledge of the pre-Hellenic world. For the general reader, one of the best surveys is H. R. Hall, The Civilisation of Greece in the Bronze Age, The Rhind Lectures, 1923 (New York: National Book Buyers' Service [R. V. Coleman], I928), abounding in well-chosen illustrations; more specialized, but fascinating in its exact detail, is Pendlebury, op. cit. For those who wish to spend more time, and are content with the greatest of the palaces only, nothing surpasses or even approaches the marvelous treatise by Sir Arthur Evans, The Palace of Minos (London: Macmillan and Co., Ltd., I921-35), with its four superbly illustrated volumes and its precise index.

A convenient summary of European archeology for this period in general, putting Crete in its total setting, is C. F. C. Hawkes, The Prehistoric Foundations of Europe to the Mycenaean Age(London: Methuen and Co.,Ltd., 1940). This book is a little too technical for easy general reading; the patient student, however, will find it rewarding. The same may be said of V. Gordon Childe, The Dawn of European Civilization (2nd. ed.; New York: Alfred A. Knopf, Inc., 1939). 
they could destroy, and most effectively when iron reached their hands, but long centuries passed before the "looters-of-cities", living in huddled war-parties amid the ruins, brought forth the civilization we know as Greek, and then only by building upon those ruins - figuratively and literally. ${ }^{1}$

Yet what the Greeks built was marvelous; minimize their achievements we should not. The great mainland or Helladic culture we have come to know chiefly as Mycenaean was in many ways the successor of the Minoan culture linked in legend with the Priest-King of Crete. Deterioration and destruction were bound up with the succession, but creativity and its attendant diversity were also interwoven; the new patterns need no justification. Even when the lords of Tiryns and Mycenae were "clouded round by the end of death", when their dominion, still trusting in its sheltering circle of flashing bronze, was shattered by the grim Dorians, their successors inherited far more than they knew. Beyond this, let us remember that the iron panoply of the Dorians did not everywhere bring them mastery; in their "return of the sons of Heracles" they still failed to conquer Attica, and the twelve great cities of lonia shut and held their gates against them. Unless we clearly see what succession and sequence really meant in the meshing or snapping of the links of bronze and iron, we cannot understand the Sparta of Lycurgus, the Ionia of Heraclitus, or the Athens of Pericles. Let us then look carefully and long at the forerunners, in differing ways and degrees, of Spartiate, Ionian, and Athenian alike; totality in the Greek multiplicity, and even unity in the diversity, may reveal their earliest traces.

III

Following up the hints given by the legends of the Greeks themselves, the spade has shown that all through the Aegean lands were centers permeated with a rich bronze seafaring culture - islands, shores, and even spots far away from the beaches where the "subtle galleys" were drawn up. ${ }^{2}$ Stripped of fantasy, the legends were not false; Crete, seat of the power of the fabled Minos, was by far the richest center, and the one from which most if not all of the others took the greater number of their guiding "Minoan" patterns. ${ }^{3}$

The hundreds of inscribed clay tablets and seals revealed by the spade in Crete are still silent; the fact that the speech of the Minoan 1 Gustave Glotz, The Aegean Civilization (New York: Alfred A. Knopf, 1925), pp. 39495; Gilbert Murray, The Rise of the Greek Epic (3rd. ed.; Oxford: The Clarendon Press, 1924) P. 5 I.

2 Hall, op. cit., map at end. It is hoped that the reader will not judge our failure to discuss the Cycladic culture too harshly; space does not permit. A convenient summary is provided by Childe, op. cit., pp. 48-57.

3 Ibid., passim.; Glotz, op. cit., passim. 
civilization, as distinct from the Mycenaean of the mainland, seemingly was not Indo-European has thus far made the task of decipherment too hard. ${ }^{1}$ Yet much has been learned by careful digging alone; it is clear, for example, that the racial strain of the bearers of the Minoan culture before its decline was almost entirely Mediterranean. This argues nothing about the language, of course; when the Greek tongue was at its prime in Attica, the overwhelming majority of those who spoke it were short, small-boned, long-headed, swarthy, darkeyed folk ${ }^{2}-$ Mediterraneans. New blood was unquestionably mingled with that of the earliest dwellers in Attica when the hosts of Greekspeakers; with their long Nordic and broad Alpine and Dinaric skulls, forced or found their way into that sheltered peninsula, but the new blood was soon absorbed, albeit in differing measure, by the various layers of the overwhelmingly more numerous Mediterranean folk of the little land. Their language the "natives" lost, except for a hundred words or so, with those characteristic -inthos and -ssos endings, but their physical type was not radically changed. So it was in other parts of the Aegean region where the Greek-speaking migrants became, in some although not always major respects, the successors of the "dwellers from the times of old". It is on philological grounds - which, as everyone knows, have nothing to do with the shape of skulls - that Minoan writings have been at least provisionally set apart from Indo-European (see on the Pylos decipherments note 1 on this page).

Nevertheless, the shape of skulls, the markings of shards, and all the evidence coming from the other yields of the digger's art almost incontestably show that the Mediterraneans of earliest Crete, forerunners of the thin overlay of indubitable Indo-European speakers

1 Angelo Mosso, The Dawn of Mediterranean Civilization, trans. by Marian C. Harrison (London: T. Fisher Unwin and Co., 1910), pp. II-43; Pendlebury, op. cit., Pp. 269-70, and the numerous references there given; Glotz, op. cit., pp. 269-70, and the numerous references there given; Glotz, op. cit., pp. 385-88; Alice E. Kober, "The Minoan Scripts: Fact and Theory," American Journal of Archeology, LII, No. I (January-March, I948), pp. 82-103.

Naturally, there is much hope that the Pylos tablets, discovered by Blegen and first deciphered by Michael Ventris and John Chadwick, "Evidence for Greek Dialect in the Mycenaean Archives", Journal of Hellenic Studies, LXXIII, 1953, will give a clue to the Minoan language. Thus far only Linear Script B has been deciphered, and that only on the Pylos tablets; those of Crete proper still resist. After the startling Ventris-Chadwick discovery that Linear Script B on the Pylos tablets uses proto-Greek (called "protoAchaean" by the decipherers), it is a bit risky to state that the Cretan tablets are probably in a non-Indo-European language. Still, the fact that Linear Script A has not been deciphered on the Pylos tablets, and neither A nor B on the Cretan, makes the "non-IndoEuropean" assumption plausible, although by no means certain.

2 William A. Halliday, The Growth of the City State (London: Hodder and Stoughton, Ltd., 1923), p. 26. But see Myres, op. cit., chap. 3., esp. pp. 79-80, and chap. 4, esp. pp. 192-209. This will be discussed later with reference to the Greeks themselves. 
who eventually became supreme, were themselves migrants. ${ }^{1}$ They seem, however, to have had no predecessors on the island. At Knossos, in the middle of the north coast, one of the largest Neolithic deposits of Europe and the Near East is represented by a stratified mound some twenty-six feet deep, on top of which the great palace was finally reared. The lowest strata show that the Neolithic culture was well advanced when they were laid down, and there is only virgin rock beneath. ${ }^{2}$ Knossos alone, among all the Cretan sites, reaches to the earlier Neolithic; the rest are more recent. ${ }^{3}$ The culture of Crete nowhere goes back to the Old Stone Age; it can only have been an import.4

No sizeable human fragments have yet been discovered at the lowest Knossos levels ${ }^{5}$, but in one Neolithic rock shelter at a site also on the north coast, but farther to the east, light-boned remains having skulls of a markedly long-headed type, with narrow faces, have been found. ${ }^{6}$ The men were a little more than five feet tall, the women a little less - slim, tiny Mediterraneans. ${ }^{7}$ The pottery shards, figurines, and the like in these and other finds point primarily to southern Asia Minor and its Anatolian uplands as the source of the diminutive culture carriers, who must have come by way of the coast and the stepping-stone islands of the Sporades and Cyclades. Yet we must be wary, for there is also some evidence of contact with Egypt, much more clearly with Libya, and perhaps with Sicily and Malta. ${ }^{8}$ Further, Anatolia, at a later date at least, was heavily round-headed - so-called "Armenoid" types - whereas the Libyans, Sicilians, and Maltese were predominantly long-headed and Mediterranean. Perhaps the bearers of the early Cretan culture were eastern littoral Mediterraneans fleeing from "Armenoid" roundheads who seized from them their Anatolian or north Syrian shoreland and fringing slopes, but who imparted to them some of the blood and much of the culture they carried westward. At any rate, the earliest settlements in Crete are overwhelmingly to the north and east of the island; although southern

1 Pendlebury, op. cit., p. 37.

2 Ibid.; Hall, op. cit., fig. 13, p. I6.

3 Pendlebury, op. cit., p. 35; Saul S. Weinberg, "Aegean Chronology: Neolithic Period and Early Bronze Age", American Journal of Archeology, LI, No. 2 (April-June, 1947) pp. $165-182$.

4 Pendlebury, op. cit., pp. 37 et passim.; Hall, op. cit., passim.

5 Pendlebury, op. cit., p. 42: "Anthropology (in the sense of anthropometry) therefore cannot help us."

6 Ibid. pp. 47, 59. See also Annual of the British School at Athens, IX (1 903), p. $34^{\circ}$.

7 Pendlebury, op. cit., pp. 47-48. See also Mosso, op. cit., pp. 409-i I.

8 Childe, op. cit., pp. 15-57, esp. pp. I7-2 I ; Edward Eyre, European Civilization (London: Humphrey Milford, 1935), I, p. I 58 ; Hall, op. cit., Pp. x-31 ; Pendlebury, op. cit., pp. 3593; Myres, op. cit., pp. 26-81, esp. summary, pp. 79-81; Toynbee, op. cit., I, pp. 323-30. 
settlements are not lacking, there are almost none in the west. ${ }^{1}$ This would argue that Anatolia and Libya, at most, should be viewed as the major sources of the Neolithic culture and its carriers, with no clear grounds for decision as to which region made the greatest contributions to either the early race or the early civilization.

Later invasions brought many Alpine and Dinaric broadheads and a few Nordic longheads into Crete, as elsewhere in the Aegean region. The skulls of the inhabitants shortened somewhat, and their stature increased ${ }^{2}$, but Mediterranean in their basic type and in their own special way they remained. As Pendlebury has said:

... The present-day Cretan, indeed, has much of the Minoan in him.... All over the island today you see the wasp waists, no longer artificially restricted but still emphasized by the long silk girdle, the slim hips, the high square shoulders, and the long legs. Many a village boy might be the direct descendant of the Cup-Bearer or the Priest-King, and who can deny the possıbility that he may be? 3

Romantically enticing this impressionistic picture is, but not necessarily false. Imaginative, but a careful, well-trained observer, Pendlebury certainly did not mean to imply that the boy who physically resembled the old Minoans was therefore like them in socially and culturally molded traits; he well knew that nurture and nature, blood and custom, race and culture, are two distinctly different things.

Most of us are fully aware of the difference in the abstract, but we occasionally forget it when talking about concrete instances. That is, we tend to confuse race and culture - "dirty Irish", "immoral French", "thrifty Scots", "enterprising Swiss", "artistic Italians". Dirtiness, immorality, thrift, enterprise, or artistry, when and if widely diffused among a given people, are not passed on in the germ plasm. Moreover, Irish, French, Scots, Swiss, and Italian are labels of peoples, not of races, which are strictly biological entities. Peoples are products and producers of culture. Further, these peoples we have just mentioned are not biologically homogeneous; each one of them includes, in varying proportion, most of the racial strains of Europe.

Anthropological commonplaces, certainly - but commonplaces may be forgotten or ignored. Let us proceed: the anthropologist tells us that when we distinguish between the biological subdivisions of the human race - race being the most general term in popular usage - we can conveniently make use of groupings in at least three diminishing degrees of generality. Terminology is not yet fully standardized, and

1 Pendlebury, op. cit., maps, pp. 36, 46, 58.

2 Myres, op. cit., p. 79; Pendlebury, op. cit., pp. 61, 267; Glotz, op. cit., p. 58.

3 Pendlebury, op. cit., p. 267. 
therefore we here take the liberty of referring to these three ways of splitting up the concept of race as stocks, strains, and breeds or, redundantly and pedantically but unambiguously, as racial stocks, racial strains, racial breeds.

The racial stocks ordinarily listed are White, Mongoloid, Negroid, and Australoid, with the American Indian occasionally added as a fifth. The racial strains, obviously enough, are much more numerous, but confining ourselves to Whites dwelling in Europe and Asia Minor, we discover that among those commonly mentioned as relevant for our present purposes are Nordics, Alpines, Dinarics, Mediterraneans, and Armenoids. (The latter, it must be granted, are sometimes held not to be properly a strain but rather a breed). Least general of the classifications, racial breeds are thought of as localized fractions of strains or mixtures thereof that have become highly fixed as a result of close- or inbreeding. Dwellers in lonely glens of the Scottish Highlands and other similarly isolated mountaineers, islanders such as the Maltese, predatory desert tribes such as the Vandals of history, are or have been breeds in this sense.

What is actually said, then, in the evocative village boy-PriestKing passage is that the carriers of the Minoan culture initially were or eventually became a breed that impressed its features on later comers with a high degree of biological effectiveness. But how vast is the cultural gulf that yawns between the village boy of the twentieth century A.D. and the Cretan monarch of thousands of years ago! So vast is it that their biological likeness, not contested here, dwindles to the rank of a mere clue as to the kinds of cultural sequence and succession that may have gone on. If a breed remains relatively the same over centuries and millenia, it is only common sense to expect more continuity in the web of society and culture woven by that breed than if there were sudden and complete displacement of one set of weavers by another. This is not because race determines culture, but simply because weavers, culture carriers, of some sort there must be, and because the processes of transmitting culture from generation to generation are in certain respects so subtle, complicated, and closely interlaced that they tend to form persisting patterns that their weavers must almost exactly duplicate if they are to be woven at all.

Mark, racial constancy does not guarantee cultural continuity! It simply increases the probabilities of such continuity, and hence heightens our common-sense expectations of finding it. As everybody knows or should know, however, common sense may occasionally be wide of what really happens. The Nordic Swede of today is of the same strain as were the marauding troopers of the days of Gustavus Adolphus who fought all over northern Europe, plundering and 
ravaging with fire and sword. But there certainly is not much cultural continuity, where political patterns and mentality are concerned, between today's professional neutrals and confirmedspeace-lovers, on the one hand, and their swashbuckling forebears, on the other. Nordic racial constancy there has been, but has there been Swedish cultural continuity? The question answers itself; in this instance common sense has failed us. What we may reasonably expect, then, is not always what we get. In Crete, what do we get?

Apparently what the evidence of racial constancy would lead us to expect. Common sense, this time at least, is not wide of the mark. Even the more sober archeologists confidently assert that from earliest to latest Minoan times - indeed, far beyond Minoan times - no significant change in racial type can be found. ${ }^{1}$ And they then go on to affirm that this high degree of racial constancy was paralleled by quite striking cultural continuity ${ }^{2}$ - until a people who had learned the ways of the sea from the Cretans gave the Palace of Knossos to the flames.

IV

The earliest settlers, who may have been forlorn fugitives in a time of "chaos and ancient night", bore with them a culture already well along in the Neolithic phase of development - their thick-thighed figurines, pottery, ground stone, and flaked obsidian remain as witnesses. ${ }^{3}$ As far back as 8000 B.C., when even Egypt lay in the murk of pre-dynastic times, and the Sumerians had not yet stirred "the Sea of the Sunrise", it may be that migrants came to Crete. ${ }^{4}$ May be; the most that can be surmised about these early dates is at best informed guesswork. Everything depends on how much muck and other assorted scraps and leavings - matter in the wrong place - was deposited on the floors of the caves and the squalid living-room and kitchen ("but-and-ben") shelters every year. ${ }^{5}$ If we assume that the settlers were much better housekeepers than the dwellers in the mudsill cabins of Kentucky, let us say, then we must put their arrival a long way back. ${ }^{6}$ If the men were messy, the women slovenly, and the

1 Evans, op. cit., I, p. 8; Annual of the British School at Athens, XII (I906), Pp. 230 et seq.; Pendlebury, op. cit., p. 61 ; Hall, op. cit., p. 25 ; Glotz, op. cit., p. 58.

2 Hall, op. cit., pp. $25,28,31,40$.

3 Pendlebury, op. cit., pp. 37, 52, et passim.; Hall, op. cit., pp. I6, 22, 31 .

4 Ibid., p. 25.

5 Mosso, op. cit., pp. 96-102; Evans, op cit., I, p. 34; Pendlebury, op. cit., p. 43.

- The reader will note that Scharff's chronology has been adopted; see Pendlebury, op. cit., p. 30r. For a very thorough and recent chronology, a little too detailed for present purposes, see Weinberg, op. cit., pp. 165-82. Radio-carbon dating has not yet been consistently applied, and for this period its plus or minus 350 or 400 years leaves something to be desired. 
children and pigs always in the parlor, then they draw closer in time. Taking highpiled dirt among the founding families for granted, and synchronizing dates with related cultures nearby, recent students of things Cretan feel that a few centuries before 4000 B.C. is a sufficiently early estimate. ${ }^{1}$

Guesswork dwindles, fortunately, when it comes to the contents of the layers, however thick or thin. Throughout the whole depth of the heap, taking from five thousand to fifteen hundred years to pile up, there are no really sudden breaks or shifts. ${ }^{2}$ Odds and ends showing that virtually every Mediterranean region east of Sicily was in contact with Crete in one way or another are encountered at nearly all levels, but they are thoroughly amalgamated. ${ }^{3}$ This is as much as to say that the absorbing and assimilating power of Cretan culture and its carriers was great; development was steady, continuous, and functionally unified. Take the metals: there is some trace of copper from Cyprus and Egypt just at the transition, or perhaps a little before, from the latest Neolithic to the Bronze Age:4 and Crete shortly thereafter learned the use of bronze from Anatolia, which had apparently found out about the alloying of copper and tin from Sumeria. ${ }^{5}$ But at this time, ranging from 3000 B.C. to a century or two later ${ }^{6}$, there is no sharp transition in other aspects of Cretan culture. Indeed, the culture traits linked with or directly embodying the uses to which the metals could be put undergo no radical alteration; for hundreds of years obsidian and polished stone still serve many purposes alongside bronze. ${ }^{7}$ The Cretans could have served as models for the conservative maxim of Macaulay: "Never eliminate an anomaly merely because it is an anomaly".

Eastern Crete, closest to Anatolia, is for some time in advance of southern and central, metallurgically and otherwise ${ }^{8}$, and those given to daring analogies might think that as between these regions evidence of rapidly contrasting changes might appear - changes like those marking the advent of the horse among the Plains Indians, or of gunpowder among Europeans. The analogies fail; Crete shows no deep-seated disjunctions in what the spade can turn up throughout $=$

1 Pendlebury, op. cit., p. 43.

2 See note 2, p. $26 \mathrm{r}$.

${ }^{3}$ Hall, op. cit., lect. I; Pendlebury, op. cit., pp. 277-79; Childe, op. cit., pp. 19-20.

4 Hall, op. cit., pp. 3I-33, 37-43; Evans, op. cit., II, fig. 3 f; Pendlebury, op. cit., p. 4I.

5 Childe, op. cit., p. 28 ; Glotz, op. cit., p. 36. But see Pendlebury, op. cit., p. 59, note I, and p. in 8.

- Pendlebury, op. cit., p. 301 ; Hall, op. cit., pp. 294-95. See also Childe, op. cit., p. 20, and Weinberg, op. cit., pp. 165-82.

7 Glotz, op. cit., p. 89; Hall, op. cit., p. 23.

8 Pendlebury, op. cit., pp. 52, 59, and esp. 301 - compare columns. 
the whole Early Minoan period, and this stretches from about 3000 B.C. or a little later to almost the end of the millennium. ${ }^{1}$ When, somewhere around 2250 to 2000 B.C., the Middle Minoan time begins, the few contrasts that do exist diminish considerably and, in spite of cataclysms attributable chiefly to earthquakes, gradually. ${ }^{2}$

This continuity and stability in early Cretan life was perhaps at a time far too remote to account for the deep impress on Greek folk memory that was clearly apparent in widespread legends of Cretan regularity, legality, and stern but even-handed justice. Probably Middle and Late Minoan governmental patterns, coupled with the rigidity of the Dorian rule established after the conquest, played the most significant part in the growth of the legends. Nevertheless, the earlier continuity undoubtedly left many traces behind, and these may well have contributed to the later practices and beliefs.

In any case, there can be no doubt that the Greeks of Plato's time and long before cherished the notion that Minos and "his exceedingly just brother, Rhadamanthus" 3 , held sway over a remarkably stable society during their lifetimes, and that in the after-life they sat in judgement over the shades of mortals, meting out reward and punishment. ${ }^{4}$ To the earthly realm of the Minos the old word kosmos was often applied. Nowadays "cosmos" means a universe that has predictability and system, but that is an extension of the originally social meaning; an ordered and orderly society was a kosmos. ${ }^{5}$ In Plato's day the extension of the term had begun, but the social sense was still vividly realized: "And philosophers tell us, Callicles, that communion and friendship and orderliness and temperance and justice bind together heaven and earth and gods and men, and that this universe is therefore calles cosmos or order, not disorder or misrule, my friend." 6 When in his old age Plato looked for a locale in which his wisdom could be put into

1 Taeger, op. cit., p. I14; Pendlebury, op. cit., pp. 52, 59.

2 Ibid., all of chap. 3 and pp. 122, 146, 148 ; Nilsson, op. cit., p. 63 ; Kober, op. cit., p. Ior.

slato, Laws, i, 624 B.

4 Od. xi, 558; Pind., Ol. ii, 75 et seq.; Plato, Apol. 41 A; Taeger, op. cit., pp. I I 2, I3.

b Anaxag. frag. 2; Herod. I, 63; Werner Jaeger, Paideia: The Ideals of Greek Culture, trans. by Gilbert Highet (New York: Oxford University Press, 1943), I, pp. ro7-108; Gabriel d'Azambuja, La Grèce ancienne, Vols. 28-29: La Science sociale, M. E. Demolins, ed. (Paris: Bureaux de la Science sociale, I906), pp. 1-344; Ulrich von Wilamowitz, Die Glaube der Hellenen (Berlin: Weidemannsche Buchhandlung, 193 I), II, p. 257; Otfried Müller, Die Dorier, corrected and augmented from the papers of the author by F. W. Schneidewin (2nd. ed.; Breslau: Josef Max and Co., 1884), 3/4, p. 2; Coleman Phillipson, The International Law and Custom of Ancient Greece and Rome (London: Macmillan and Co., I9II), I, p. I95; Pierre-Maxime Schuhl, Essai sur la formation de la pensée grecque (Paris: F. Alcan, I934), p. I92; Abel Rey, La jeunesse de la science grecque, Vol. I: La science dans l'antiquité (Paris: La Renaissance du Livre, 1930-48), p. 69.

- Plato, Gorg. 508 A. 
practice without waiting for the time when kings become philosophers and philosophers kings, he fixed on Crete. ${ }^{1}$ There he held discourse, as the wayfaring Athenian, about his Laws - there, in a land where the magistrates were still called "those who put in order", the kosmoi. ${ }^{2}$

We have moved far ahead, however, of the time with which we are now directly concerned. Regardless of what Plato and other Greeks thought about the good old days, we do have archeological evidence about an apparently quite unusual degree of cultural continuity in certains periods of Minoan life. There may have been something special about Crete that would help to account for this continuity. Let us therefore search, using the known facts cautiously and speculating only when we must.

Minoan Crete was quite clearly in a special position in the world of its day. That position was not merely a matter of geography in the sense of simple spatial location at a given point on the face of the earth, with these or those "determining topographical and climatic factors" thrown in for good measure. ${ }^{3}$ We cannot ignore geography, but we must also note that the Crete of the Minoans was not the Crete of the Greeks, and the Crete of the Venetians was not the Crete of the Turks. Geography furnishes necessary conditions, but not sufficient conditions. Without neighbors of certain kinds, certain methods of travel, certain features of the Cretan culture itself, the island would always have been what it now is - an utterly insignificant streak on the European-Near Eastern map. It has remained in the same spatial location, but its vicinal position has changed. "Vicinal" indicates that "what is important about the position of a people is not only the land under their feet, but also the neighbors about them."4 The special vicinal position of Crete during some fifteen hundred years of the Minoan period gave an unusual balance of isolation and accessibility,

1 Plato, Laws, passim.

Phillipson, op. cit., I, p. I95.

3 In fairness to contemporary geographers, it should be said that very few espouse the determinism of a generation or two ago. For a convenient summary, see Harry Elmer Barnes, Howard Becker, and Frances Bennett Becker (eds.), Contemporary Social Theory (New York: Appleton-Century, 1940), chap. 7, esp. pp. 203-1r, "Critics of Geographical Determinism." Lucien Febvre's long and searching study is here highly relevant - see his A Geographical Introduction to History (New York: Alfred A. Knopf, 1925). Long ago, of course, Fustel de Coulanges attacked geographical determinism, where the Greeks are concerned, in his The Ancient City, trans. by Willard Small (roth ed.; Boston: Lee and Shepard, 1940), pp. 269-70 et passim.

- Howard Becker, Vicinal Isolation and Mental Immobility, in: Social Forces XI, No. 3 (March, 1933), pp. 326-334 and the extensive footnotes. See also Howard Becker, Man in Reciprocity (New York: Frederick A. Praeger, 1956), use index for "isolation", "accessibility", etc. 
and the culture flourished in ways engendering among the Greeks the legend of the kosmos of the Minos. This is not to say that this "establisher of order" was loved; in Attica, indeed, the Minos was a hated name. Still, it was a name evoking the reluctant respect granted to the symbol of the overlords of a great, balanced culture.

On one side of that balance was the vicinal accessibility just noted; this was heavily weighted with geographic conditions. They were conditions, not determinants, true enough, but to throw out geographic determinism is not to discard vitally important facts such as land- and sea-forms, weather, and all the other inevitabilities with which the carriers of any culture, no matter how advanced, must reckon. ${ }^{1}$

To say that Crete marks the southern edge of the Aegean Sea is to say a great deal. Well might the Greeks think of Poseidon not only as the god of the sea and the waters upon and beneath the earth, but also as the earth-shaker. The Eastern Mediterranean region, and especially the Aegean, has been folded and crumpled time and again; Poseidon cleft the mountains with his trident that the waters might pass. The splitting and squeezing to which were subjected the great mountain spans running from the Asiatic Pamirs, "the roof of the world", across into Europe and Africa brought more than tortuous twists and crosswise fissures; the sustaining crust beneath the inrushing torrents collapsed. Earthquake upon earthquake rumbled as the shocks of subsidence brought low the mountain peaks, until at last Poseidon's work was almost over and waves washed about island chains that had once stretched as unbroken, lofty ridges between the lands of sunrise and sunset. ${ }^{2}$ The Aegean region became what it has since been, at once the Holy Sea (bagion pelagos) and the Archipelago. ${ }^{3}$ Here, as Myres has said, "Nature, like Man, has an infinite diversity of detail, which a romanticist might well call caprice, and a Greek respected as... [tyche or mysterious chance], while he shrank from converse with it."4

But we, being neither romanticists nor Greeks, must hold converse with the amazing Aegean. Crumpling, twistiug, and settling mean that its fringes are not simply foreshores and outrunners of either Asia Minor or the Balkans, even though the highlands of both sink downward into it. Island-sprinkled, cut up by far-jutting capes and

1 Howard Becker, "Pastoral Nomadism and Social Change", Sociology and Social Research, XV, No. 5 (May-June, I 93 I), pp. 417-427.

2 Eyre, op. cit., I, p. 93; Toynbee, op. cit., I, pp. 323-24; John L. Myres, The Political Ideas of the Greeks (New York: The Abingdon Press, 1927), p. 60.

3 Toynbee, op. cit., I, p. 326.

4 John L. Myres, "Geography and Greek Colonization", Classical Association Proceedings, ed. by John Murray, VII (1910), p. 68. 
headlands, and sheltered from the south by the long sea-wall of Crete against which the great waves surge, it also is not a mere bulge of the Mediterranean like the Adriatic. To the far northeast lies what was once called the Hostile and later and euphemistically the Hospitable Sea, but its "black waters" connect with the Aegean in the most haphazard and freakish way. They must pass through the constricted slit of the Cimmerian Cattle-Crossing, the Bosphorus, through the Inlet Sea, the Propontis, and through the long, narrow defile of the Road to Greece, the Hellespontine sea-ridge, "where east upon west waters break". The Aegean, then, is by no means just an open strait linking the main Mediterranean with the Black Sea; it is a region all its own. ${ }^{1}$

Life on the islands and shores and bare-spined peninsular uplands of this region is attended by its own peculiar hardships, but the lot of the seafarer is in many ways less adverse, and often a pleasant one. Often, not always! In the bad season the winds blow rough and cold; more, they veer, gust, and flaw in at times cyclonic ways. During the long sailor's summer, however, the regularity of weather and wind can be counted on as in few other regions - Cape Malea itself, where in "the blighting times" the unwary mariner gives up hope of reaching home ${ }^{2}$, can be safely rounded. Treacherous currents and eddies, like the Maelstrom or Corryvreckan, are seldom encountered; the whirlpools of Euripus and Charybdis evoked the awe they did precisely because they had so few counterparts. The tides of the Atlantic deeps exert little pull through the Pillars of Hercules, and the Mediterranean itself is so comparatively shallow that the moon does not get a good grip; Aegean tidelessness is the result. This and the prevalence of pure limestones along the shore mean that the Aegean is bright and limpid, "betraying rocks, shoals, and tunny alike". ${ }^{3}$ Harbors and their hazards remain stable in depth and shape, and the air, clear and dry throughout much of the year, gives the mariner a safe line of sight from headland to headland.4

Standing out in high relief, promontories themselves can not only be seen for long distances, but back of them, in many cases, mountain masses loom that serve as land-and seamarks throughout whole stretches of the Aegean. Mount Athos, for example, caps the projecting eastern prong of the Chalcidicean peninsula with its height of more

\footnotetext{
1 Myres, Who Were the Greeks?, pp. 4-5; Alfred Zimmern, The Greek Commonwealth ( 5 th ed. rev.; Oxford: The Clarendon Press, 193I), p. 27; Alexander Kinglake, Eothen (Edinburgh: William Blackwood and Sons, 1 893), chap. 3, at beginning.

2 Strabo, II, vi, 20, quoting a proverb.

3yres, Classical Association Proceedings, VII, p. 55.

4 Od. iv, 340-44; Semple, op. cit., p. 589.
} 
than six thousand feet. Every navigator of the north Aegean can steer by it; at the summer solstice it casts a shadow forty miles away, making early twilight in the marketplace of Myrina on the island of Lemnos. ${ }^{1}$ From the top of Athos can be seen Olympus and the peak of Pelion in eastern Thessaly, as well as five-thousand-foot Dirphys in central Euboea, which can in turn be descried from the pinnacle of Pentelicus - little short of four thousand feet, and in easy view of Athens. ${ }^{2}$ The summit of Samothrace is visible for a radius of almost a hundred miles; Homer sings that from its height "all Ida was plain to see; and plain to see were the city of Priam, and the ships of the Achaeans". ${ }^{3}$ Aeschylus tells how the news of the fall of Troy was flashed by signal fires from peak to promontory to island to mainland across the Aegean to the palace of Mycenae in the Peloponnesus, and every landmark that pulses in that rhythm of Clytemnestra's chant was long part of the lore of the Greek sailor. ${ }^{4}$ The Ocha massif, bulking almost as large on southern Euboea as Mount Dirphys does on central, is in view from Halonnesos on the north, Naxos on the south, and Chios on the west. Chios itself has a peak, Pelinnaios, almost four thousand feet sheer from the sea at its feet, visible for the full distance across the central Aegean to Euboea - seventy-five miles. But it is in the southern Aegean that the seaman is really well guided; leaving Rhodes, Mount Atabyris, towering more than four thousand feet, stays in view of the masthead lookout until the Cyclades spread before him, and from the remoter Cyclades his keen eyes discern the seven-thousand-foot summits of eastern Crete. Drawing closer but still nearly one hundred miles away, he glimpses the central crown of Mount Ida ${ }^{5}$, a cloudy wreath eight thousand feet and more in air, and knows ${ }^{6}$ that at last he has made his landfall.

Fascinating indeed is evidence like this, and abruptly we must hark back to the reminder that what is important about the position of a people is not only the land under their feet, or the sea that stretches before their eyes, but also the neighbors about them. Many peoples who have egregiously failed to navigate have been excellently located, from the merely spatial standpoint, for the development of navigation.

1 For figures of Aegean visibility in general, see Carl Neumann and J. F. M. Partsch, Physikalische Geographie von Griechenland (Breslau: Wilhelm Koebner, 1885); for this reference see Pliny, iv, 23; A poll. Rhod., i, 601-606.

The reader should note that all through this section the place-names are ancient, not modern, though the present tense is frequently used.

2 Semple, op. cit., pp. 586-88.

3 Il. xiii, 13.

4 Aesch. Agam., 28 I-3 Io.

5 Semple, loc. cit.

6 Neumann and Partsch, op. cit., p. 147. 
In Greece, those incurable landsmen, the later Boeotians, provide an outstanding example, and Febvre has given scores of others collected from all over the world (see note 3, p. 264). Seafarers must learn to be seafarers, and the process is often long and roundabout. What is obvious to those who carry with them the long legacy of the past may not be at all obvious to man still groping his way about a bewildering and frequently terrifying maze. Opportunities to take ship and risk life on a fickle or treacherous element must be recognized as opportunities.

The Cretans vastly bettered the sea-lore imparted to them, but that lore was imparted. Drawings of early Aegean boats show them to have been oared but mastless, with fish ensigns decking the prow. Similar drawings of Red Sea boats, used by pre-dynastic Egyptians, indicate that both peoples had early learned to plough the sea for a full belly, but there seems every likelihood, given the earlier record of man in Egypt, that the Nile food-quest came first. Masted vessels are another story, however; present opinion is that both Egyptians and Cretans learned how to ease the work of the rower from those Syrian sailors whom we later know as Phoenicians. The Syrian seafarers, in turn, learned to work the Lebanon cedar of their big vessels with copper tools, and the knowledge of copper probably reached them through Anatolia from the Asiatic hinterland - where we do not know, or when. What we do know is that the resolute or desperate settlets of earliest Crete learned much of the craft of sea-borne travel from, neighbors. ${ }^{1}$

It was to the north side of the island that the Cretan sailor most frequently pointed his prow throughout the Minoan time. In the Odyssey, which seems to preserve much sea-lore of the Late Minoan age, the south side of Crete is still "top-side" 2, washed by an "upper sea" 3 that leads out into the tossing, trackless wastes of the long and vexatious ${ }^{4}$ way to Egypt. Once near the low-lying African coasts, with their marshes, sandbars, and flattened reefs stretching for hundreds of dreary miles ${ }^{5}$ on either side of the single sheltering cove behind the island of Pharos ${ }^{6}$, the danger of shipwreck was ever present. The hardy Cretan sailors who, in times when Egypt-seeking trade was of paramount importance, often made the treacherous voyage thither, must have jeered at their pampered fellows of the Aegean run, never

1 Mosso, op. cit., p. I3; Evans, op. cit., 2, p. 26; Childe, op. cit., p. 53; Hall, op. cit., pp. 34-39.

${ }_{2}$ Myres, Classical Association Proceedings, Vol. VII, p. 52.

3 Ibid.

4 Od. iv, 485 .

5 Diod. Sic. I, iii.

6 Strabo, XVII, i, 6 . 
able if they tried to get more than forty miles from a safe harbor, a shielding island, or at least an inhabited shore. ${ }^{1}$

Yet, though Crete faces north and the bulk of the traffic ran north and east in ordinary times, the trade with the neighbors to the south, with the rich, wise, and mighty Egyptians, and to the southwest, with the prosperous Libyans dwelling in fertile Cyrenaica, went on even in those Early Minoan days when ships were little more than longboats. ${ }^{2}$ This was not all: to and beyond the faraway Italian heel the Cretans ventured northwestward, perhaps acquainting themselves with the dark rites of those who much later became the Etruscans, as well as with their wares. Cretan keels stirred the bays of Hither Sicily; through the uncanny Straits of Messina to the shores of Farther Sicily they voyaged - and to the Lipari Islands, and, it is more than likely, to distant Sardinia and Corsica as well. Far toward the setting sun, the inhabitants of Malta perhaps compared the "red-skinned" Cretan faces ${ }^{3}$ with their own, so similar in hue, and the good harbor lying beyond the Tunisian promontory, where Carthage later flourished, may not have remained unknown to the bolder Cretan captains daring to defy hostile currents. Did they venture farther still - to Spain, to Britain? Spanish silver and British tin found their way to Crete - that much we know.

The Cretan captains, when they returned with their gains and booty and their tales of faraway marvels, must have scoffed at the naive landsmen's reckoning of simple distance. ${ }^{4}$ When the wiseacres of the ports traced the routes on the sandmaps, discovering that Crete lies as near to the Nile as to Troy, to Cyrenaica as to Mycenae, to Italy as to Syria, to Sicily as to Cyprus ${ }^{5}$, like as not the seawise skippers roared with laughter. "Distance on that sand-table means nothing,

1 Semple, op. cit., p. 587 .

2 Mosso, op. cit., pp. 266-85; Hall, op. cit., pp. 34-39, esp. p. 38 ; V. Gordon Childe, Man Makes Himself (New York: Oxford University Press, 1939), pp. 199-201.

3 Phoinikes, likewise used for the Phoenicians, C. R. N. Bradley, Malta and the Mediterranean Race (London: T. F. Unwin, I912), passim, but esp. pp. 17-2I; Glotz, op. cit., p. 6r. On the Etruscans, see Glotz, op. cit., p. 224. On contacts with the Italian peninsula in general, see Mosso, op. cit., pp. 379-400. For the farflung nature of Cretan navigation, see Richard Hennig, "Die westlichen und nördichen Kultureinflüsse auf das antike Mittelmeerwelt", Klio, XXV, Nos. I-2 (1932), pp. I-II. For trade, etc., with Malta and Sardinia, see Hawkes, op. cit., pp. I55-56; Childe, The Dawn of European History, pp. 245-57. For early Mediterranean trade in general, see Mosso, op. cit., pp. $360-78$.

4 This is inserted with malice aforethought; undue reliance on computations of simple distance is evident today, Cf. Glotz, op. cit., p. 29, and Murray, The Rise of the Greek Epic, p. 36. Even disregarding vicinal position, some attention should be paid to the conditions of early navigation.

5 Ibid. 
you lubbers; have you ever held the steering-oar when headwinds roar and stars, moon, and sun alone show the course?" But though the ease of the creeping navigation ${ }^{1}$ north- and eastward, when contrasted with the risks of the open sea elsewhere, made nonsense of the equating of one journey with another, journey far and wide the venturesome Cretan nevertheless did. Round about him were the most brilliant cultures of the ancient world, and he went forth to partake and to profit. Having served his apprenticeship on the Aegean pond, he voyaged to the farther reaches of the whole eastern half of the Mediterranean, and perhaps to the remoter west as well. Before long his neighbors - among them, at various times, Assyrians, Kassites, Hittites, Phoenicians, Libyans, Sicilians, Hebrews, and Egyptians - set their scribes to writing about "the Peoples of the Sea". ${ }^{2}$

Without these neighbors the Cretan would have amounted to little; his early culture was not at odds with itself, but it was by no means rich in techniques, and the resources of his island home were not great. Granted, timber for his ships must have come from his own dense cypress woods; we know that some of the beams of the great palace at Knossos measured sixteen inches through. ${ }^{3}$ To work that timber, however, he had to fetch the obsidian of Melos ${ }^{4}$ and the copper of Anatolia, Cyprus, and Egypt. ${ }^{5}$ When he finally learned to make use of his scanty domestic copper ${ }^{6}$, the harder bronze still lured him eastward, and when the secret of the bronze alloy of Anatolia came into his hands, he still had to travel afar, perhaps to Sicily 7, for tin to make that alloy. Gold he brought from Egypt and Lydia, silver from near the Hellespont, Syria, and the northern mainland that was not yet Greece. ${ }^{8}$ Naxos emery for whetstones, jewel- and seal-cutting, and the rapid grinding of hard stone vases was likewise imported ${ }^{9}$, as were also diorite, liparite, marble, and similar materials on which the grinder exercised his craft.10

1 Semple, op. cit., pp. 64, 585-86. Cf. Thuc. vii, 26, 31, 33, 35; vii, 50; vii, 99, ror.

2 In subsequent centuries the Egyptians use this term to refer to the tumultuous assortment of wanderers flooding the Eastern Mediterranean during the time of the "Uprooting of Peoples", i.e., the Great Migrations.

3 Pendlebury, op. cit., p. 6; Glotz, op. cit., p. I 88; Hall, op. cit., pp. 32-39; Myres, Who Were the Greeks?, p. 6 and note 3, p. 546.

4 Hall, op. cit., pp. 22-23; Myres, Who Were the Greeks?, pp. 6, 239, 278-79; Pendlebury, op. cit., pp. 39, 90; Glotz, op. cit., pp. 30, 33, 38, 88 .

5 Hall, op. cit., pp. 3 I-38.

6 Ibid, pp. 3 I-32, esp. footnotes $x, 2$ and 3.

7 Glotz, op. cit., p. 36; Myres, Who Were the Greeks?, p. 278.

8 Ibid, pp. 278-279; Hall, op. cit., pp. 54-56; Pendlebury, op. cit., pp. 72-73, I 2o. Note, however, that there is little if any convincing evidence of the mining of silver at Laureion (in Attica) before 600 B. C.

Hall, op. cit., p. 42.

${ }^{10}$ Ibid., p. 49. 
So might the list be prolonged, but what is important for us here is what archeology shows of the startlingly rapid development of the ways of using these and the domestic materials as well. When the Early Minoan period reaches its halfway mark, about 2500 B.C., the pottery, although imitative of Egyptian models and still not wheelturned, has begun to acquire its own distinct qualities, the gold and silver jewelry takes on a Minoan cachet, and the ivory and steatite seals are finely cut. ${ }^{1}$ A delicately discriminating eclecticism there still is, but there is every sign that the peculiar and unmistakable Minoan style, miniature rather than monumental, will soon emerge - a style that in spite of manifold changes will remain recognizably the same, and that in its inimitable brilliance will gain for the Minoans a reputation for artistic excellence throughout the whole ancient world. ${ }^{2}$ We need not be Frenchmen like Glotz to say that they were the Parisians of their day ${ }^{3}$, nor disciples of Lafcadio Hearn to call them the Japanese of the Mediterranean. ${ }^{4}$

Before the burst of brilliance appears, shifts in the Cretan positions of cultural dominance become manifest. Although the developing culture of the Cyclades is demonstrably influencing its sources on the eastern end of Crete, so that the stem benefits from the offshoot, as it were, the eastern centers nevertheless are slowly losing their preëminence. Knossos is gradually gaining, but still lags. It is in the south, as Early Minoan times draw to a close, that the more rapid efflorescence appears. The higher qualities of the Minoan culture start to emerge, and from this and other evidence the archeologist can infer, without too much risk, that population and prosperity markedly increased. The traffic with Egypt and Libya, long important, was beginning to exert its really great effects. 5

Among these effects was the building of a wide, solid road across the middle of the island, from Knossos in the north to the seaport just beyond the southern palace of Phaistos. This port, Komo, was clearly the focal point of the Egyptian traffic; the stimulus it provided must

1 Pendlebury, op. cit., pp. 87-9o.

2 Glotz, op. cit., pp. 306-309; Pendlebury, op. cit., Pp. 139, 145; Hall, op. cit., pp. 154, I56-57.

3 Mres, who Were the Greeks?, pp. 75-76; Annual of the British School at Athens VII, (I901), p. 57, fig. I7; Glotz, op. cit., pp. 66, 82.

1 Ibid., p. 309; Hall, op. cit., p. 13 I.

5 Carl Schuchhardt, Die Burg im Wandel der Weltgeschichte (Wildpark-Potsdam: Akademische Verlagsgesellschaft Athenaion, I931); Pendlebury, op. cit., pp. 59-60, $74-75,78$. 
have been intense. The majestic palace of Knossos was founded; the earlier, smaller palace buildings were leveled to make room for it. The Middle period begins; we date it about 2 100 B.C. or a trifle earlier, and it seems clear that at this time the rulers of the central core of Crete, with the northern part in the van, finally took the lead over those of the east. ${ }^{1}$ There is ample evidence of the setting up of a strong monarchical power that even at this time may have controlled the entire island and all Cretan relations with neighbors; the Priest-King of Knossos probably took precedence over his domestic rivals. Minoan political life, then, began to be thoroughly unified. ${ }^{2}$

Deeply marked contrasts in the major aspects of the Cretan culture, either as between regions or successive phases, there had never been; as we have seen, a very considerable degree of functional unity had prevailed from earliest times. Now the power structure, not infrequently the last aspect of most cultures to enter into whatever functional unity is achieved, reached the point of incipient integration in Cretan domestic affairs; and foreign affairs began to come under better control than had hitherto been possible. The outlines of an ordered and orderly society took plainer form; the word kosmos becomes still more applicable. Of compassion there was probably little, and of benevolence not much more, but by contrast with the disorders besetting neighboring peoples, the political unification of Minoan society, however lacking in absolute completeness and in the softer graces, carried a special virtue within itself: calculability. Foresight might not prove to be vain. Tomorrow might be another day, but at least the Cretan had some reasonably clear notion of what tomorrow might bring.

This relative unification of Middle Minoan economics, politics, religion, and community life began at about the period when the Pharaohs of the brilliant Eleventh and Twelfth Dynasties of Egypt started their exacting task of restoring the grandeur of their country after the "Time of Troubles" - invasions by "Asiatics" and Libyans aggravated by uprisings among the oppressed Egyptian poor. These monarchs, with Amenemhat I conspicuous among them, regained authority by conquering their foes within and without and setting up the Rule of the Just Laws. The Middle Kingdom, as their reign came to be called, was marked in its later phase (down to shortly after 1700

1 Ibid., pp. 94-98; Glotz, op. cit., pp. 146-56 (somewhat speculative).

2 Hall, op. cit. Pp. 94-108; Myres, Who Were the Greeks?, p. 175 ; Pendlebury, op.cit., pp. 94-98; A. R. Burn, The World of Hesiod (New York: E. P. Dutton and Co., 1937), p. I6, has an interesting reference to the Pax Minoa. Schuchhardt, op. cit., pp. 66-68, calls attention to the fact that at this time was built the only teal fortress-tower of Knossos. It had deep dungeons, too, but was demolished before the end of the Middle Minoan period to make more room for the unfortified palace. Sce also Evans, op. cit., I, pp. I 36 ct seq. 
B.C.) by peace and well-being. 1 Middle Minoan Crete and Middle Kingdom Egypt flourished togethe ${ }^{2}$

Clearly, the Just Pharaohs did not establish their successful rule without the use of force; it is to be suspected that the Priest-King of Knossos likewise did not rely altogether on persuasion. The palace dungeon and the abundance of weapons at the disposal of himself and his erstwhile or current rivals - the massive broadsword of Mallia, axes, spears, daggers short and long - go to show that. ${ }^{3}$

Still, the Minoan culture may have been much less warlike than others of its day, ${ }^{4}$ battle-scenes or anything closely approaching them on frescoes, carvings, and vase-decorations seem to be of the utmost rarity. Gorgeously bedizened warriors in dress-parade formation or doing the manual of arms with a flourish occasionally pose for the artist, it is true, and there is a sprightly picture of a proud Cretan captain prancing along with his Negro mercenary troops or palace guards at the double-quick march.5 Grim resolve or even rigid discipline are not apparent, however; although kilts, sporran-like codpieces, and even plaids ${ }^{6}$ deck many many of the Cretans, especially as their pictures figure on the walls of Egyptian tombs, they do not seem to breathe the "dour Scots temper o' the lads wha ne'er get their fill o' fechtin'." A bit of embossed silver found at Mycenae, probably from a rbyton or drinking vessel made for a mainland warlord by a Minoan craftsman, displays the tumult of a sea-attack, with a wild-looking archer, perhaps a Northern pirate, among the struggling men, but this is late and of no great evidential value. ${ }^{7}$ Better testimony is yielded by an indubitably Minoan steatite fragment; the archer is of the same non-Cretan type, however, and may have been either an enemy or, more probably, a mercenary. Hiring others to fight is not calculated to foster the martial spirit of the employer. ${ }^{8}$

Taking it for all in all, it is hard to believe that the Cretans reveled in the joy of battle during Minoan times. Cruel human sacrifices, in the Cretan case harking back to cannibalism, there may well have

1 Howard Becker and Harry Elmer Barnes, Social Thought From Lore to Science (2nd ed. rev.; New York: Dover Publishers, 1952), pp. IO-I I and notes - hereinafter this work will be referred to as STFLTs; Pendlebury, op. cit., pp. I 20-2 I, I 43-44.

2 Glotz, op. cit., pp. 203 ; Pendlebury, op. cit., pp. 94-146.

3 Schuchhardt, op. cit., pp. 66-68 (see our note 5, page 20); Hall, op. cit., pp. 88-92; Glotz, op. cit., pp. 84-Io I ; Pendlebury, op. cit., p. I I 8.

4 Nilsson, op. cit., p. 79; Nilsson, The Minoan-Mycenaean Religion and its Survival in Greek Religion (2nd ed. rev; Lund: C. W. K. Gleerup, 1950), pp. 41 I-I 2; Myres, Who Were the Greeks?, pp. 279-80; Glotz, op. cit., pp. 394-95.

5 Hall, op. cit., pp. I 19, I58-59, 206; Glotz, op. cit., p. $39^{8}$.

6 Hall, op. cit., pp. I83, 262, 267 ; Glotz, op. cit., pp. 68-71.

7 Hall, op. cit., pp. 135-36; Glotz, op. cit., p. 336.

8 Myres, Who Were the Greeks?, p. 28I; Glotz, op. cit., p. 7o. 
been; many clues lead that way ${ }^{1}$ - religion can be heartless. Prolonged warfare and frequent civil strife are something else again; of these there is little trustworthy evidence. Moreover, for a long time the Cretan kingly dwellings had not been fortified, partaking more of the nature of elegant residences than of strongholds for offense and defense - Petit Trianons instead of Carcassonnes ${ }^{2}$, palaces rather than castles. What destruction they suffered before r 400 B.C. was apparently from earthquake; efforts by some scholars to conjure up visions of assaults and palace-smashings during the Middle Minoan period run hard against the archeological evidence of terrific upheavals that only Poseidon the Earth-Shaker could wreak. ${ }^{3}$ The Minoans at this time were sheltered by the floating ramparts of their fleet against enemies from without ${ }^{4}$, and of effective revolt or internecine struggle there is no dependable sign.

Granted, it is entirely possible that after some or all of the appalling earthquakes this or that local potentate, freed for a time from the surveillance of central authority, might take matters in his own hands and attempt to aggrandize himself-but there is no convincing evidence of razing, burning, and looting. Further, it is certainly quite possible that the underlings and the oppressed - and in view of the fact that Crete was not the Kingdom of Heaven, such persons probably made up a goodly part of the population - may have seized the chance brought by temporary disorganization after catastrophe to stage revolts. Toynbee, determined to insert an active "internal proletariat" at certain predetermined stages, because of his cyclical theory presumably holding for all societies, feels that this must have been the case in Middle Minoan Crete. However plausible this may be, however, it cannot be too strongly emphasized that tangible evidence is lacking. Analogies drawn from other societies have a certain persuasive pull, but that is the most that can be said.

Finally, and in anticipation of pages soon to follow, it must be pointed out that even if we were to grant the various and, incidentally, conflicting contentions now current, and were to assume that a revo-

1 But see Glotz, op. cit., pp. 253-54.

2 Schuchhardt, op. cit., p. 95; Taeger, op. cit., I, p. I I4; Hall, op. cit., pp. ro9-I 2 I; Glotz, op. cit., pp. I56-57. The great source of evidence is of course Evans, op. cit., all four volumes, passim. Glotz, op. cit., p. 38 , maintains that even some of the later palaces were fortified, but the evidence does not seem to bear this out. See our note 2, p. 272. 3 See Myres, Who Were the Greeks?, p. 28I, for speculation on the evidence; Childe, op. cit., p. 27, for a brief summary; and Péndlebury, op. cit., pp. 146, I48, I I, I 54, I 75, I 80 for a sober, restrained interpretation by an outstanding archeologist familiar with the various alteenatives. See Hall, op. cit., pp. rog-1 2 for a "revolution" interpretation of the destruction at the close of Middle Minoan II, and Pendlebury, op. cit., p. Io9, for the possibility of a small raid at Knossos.

Glotz, op. cit., pp. Is7-6o. 
lution of the oppressed, a revolt of subordinate Cretan rulers, a raid from overseas, some of these and other possibilities in combination, or all of them together, can be assumed as accounting for the havoc of 1700 B.C., we should still have a Pax Minoa lasting until 1400 B.C. Three centuries is a long time; the famous $P a x$ Romana was in actuality little if any longer, and the late nineteenth- and early twentiethcentury Pax Britannica occasionally referred to was hardly a peace at all, and in any case much less than a century in duration. Even the bare possibility of a three-hundred-year kosmos and its attendant tranquillity, though for some of that period limited to Crete itself, would seem worthy of respectful attention; in this uneasy modern day not a few of us would settle for prospects of one hundred or perhaps less.

Returning now to the Middle Minoan world, and reiterating: there is little evidence of aggressively martial spirit in the frescoes and other pictorial representations. Furthermore, the palaces were not fortified in any significant degree, and even their sites were very poorly chosen from any military standpoint, being on low ground or open territory rather than on hill- and mountaintops or in defensible glens. There may well have been an elaborate system of social control going as far as spiritual coercion - prescribed societies are by no means rare - in political as well as more strictly religious matters. Why not? The King was also Priest. In addition, we can be reasonably sure that some physical coercion, in at least the form of a vigilant coast guard, a gendarmerie, and a police system protecting the roads, way-stations, and cities was planfully exerted. Why not? The Priest was also King. Nevertheless, when all is said and done, the evidence now at hand points to a minimum of delight in strife for its own sweet sake.

The vicinal accessibility of the Minoans, then, was quite possibly or even probably an accessibility bringing with it a relatively peaceful interchange of goods - indeed, "orderly commercial intercourse" may not be too strong a term. This is tantamount to saying that there was also a high degree of social accessibility. The trader from other lands was free to come and go, and so likewise, as the Egyptian evidence shows, was the commercial traveler from Crete at liberty to carry on his affairs in the port towns, at least, of other countries. The forms of "bringing tribute from the Isles of the Very Green" were observed when dealing with the Pharaohs, but it is quite clear that they were mere forms. The Egyptians possessed no Mediterranean navy of any consequence; when Cretans came, it was because they had good business reasons for coming, not because they were captives or browbeaten emissaries from a colonial dependency. Rigid restrictions on 
social intercourse dropped into the discard; the intermingling of peoples was tolerated and perhaps even approved. Further, mental accessibility followed closely in the tracks of vicinal and social; a common universe of discourse began to develop. Egyptian writing influenced Cretan, as might be expected, but Egyptian schoolchildren were given the task of making lists of Cretan proper names, which is somewhat astonishing. Egyptian motifs appear on Minoan seals, and some of them may have had magical significance - again nothing remarkable in view of Egypt's reputation as a land of wonders. What might not be expected, however, is the fact that Cretan healing recipes and mumbo-jumbo formulas had a vogue in the domain of the Pharaohs. The two peoples had begun to gain entry to each other's minds, albeit in ways that merely show how powerfully the charm of the exotic was at work. ${ }^{1}$ After all, though, mental accessibility quite frequently gets its start in the realm of the non-rational; the wise stranger is first of all a mysteriously enthralling stranger. Abraham was not the only host of whom it was related that in welcoming strangers he had entertained gods unawares. And magic may be no respecter of persons.

In the Middle Minoan period, trading emissaries must have been busy; the evidence of manufacture for export is already abundant. ${ }^{2}$ Cretan pottery found high favor with the Pharaohs, and when the slow wheel began to be used and cups and other vessels of eggshell thinness were turned out, the elegant ware surpassed all competitors.

1 Helene J. Kantor, The Aegean and the Orient in the Second Millennium (Bloomington, Ind.: Principia Press, 1947), p. 32; Glotz, op. cit., pp. 371-86, esp. p. 385; Pendlebury, (p. cit., pp. 269-70.

2 To say this, and more especially to stress the likelihood of the peaceful interchange of goods, runs counter to a point of view that at present enjoys some popularity. Reacting violently, and with a good deal of justification, against Meyer, Pöhlmann, and a number of other scholars who have excessively "modernized" the ancient world by tepresenting it as having been pervaded by "national trade rivalries", "economie power politics", "industrialization", "early high capitalism", and the like, several writers have swung to the opposite pole.

Let us take Bücher, Max Weber, and Hasebroek as among the more prominent of the many who might be chosen as examples. Bücher, rigidly bound by late nineteenthcentury dogmas of social evolution, insisted that there was no import-export trade whatever in the early Hellenic world, much less in the still earlier Minoan of which in his time there were only inklings. Max Weber, determined to salvage the Calvinism-capitalism thesis, could see only "the political man" in the ancient period, never "the economic man". His basic contention was that although "booty-capitalism" was undeniable, there was no significant trace of any other kind. The Calvinism argument runs in a circle, and there is much witness of peaceful trade even in that Geometric period when in some Greek regions, it must be granted, "war, trade, and piracy are an indivisible trinity". Hasebroek, a follower of Weber, has lavished great ingenuity on the extensive evidence of primarily economic interchange in the effort to explain that evidence away. He has succeeded in deflating a 
Even with the introduction of what was perhaps a Cretan invention, the quick wheel, and the attendant decline in quality caused by the increased thickness of the vessels it was thenceforth so easy to turn out by mass production ${ }^{1}$, the further perfecting of the gorgeous polychrome decorations held the popularity that had been gained. ${ }^{2}$ Not merely as objets d'art, but also as utensils of customary purchase, Cretan cups, jars, and vases were available at many places in Lower Egypt, for example, during these Middle Minoan times. ${ }^{3}$ From the high development of methods of sealing the more appropriate receptacles, it is clear that they were shipped abroad full of wine, olive oil and other liquids of which Cretans were either producers, middlemen, or both. ${ }^{4}$ Among the export containers at Komo and other port towns many tablets have been discovered that are almost certainly bills of lading. ${ }^{5}$ The deciphering of the Minoan number system, where scholarly efforts have been more successful than with the language as such, enable documents of this kind, crowded with numbers as they are, to be guessed at with some likelihood of accuracy. 6

The Phoenicians had probably begun to compete for maritime dominion, but the full tide of their westward expansion had not yet risen. ${ }^{7}$ The Egyptians, though they imported the cypress of Crete and the cedar of Lebanon for keels and masts - Egypt itself producing little suitable ship timber ${ }^{8}$ - rarely if ever ventured to contest in the Mediterranean the high-seas supremacy of the Keftiu, as they called number of the exaggerated claims of the Meyer school, but he is so obviously a partisan that even at points where he should be taken very seriously, it is hard to do so. Moreover, he ignores or slights the Minoan, Mycenacan, and Asianic Ionian data ("Asianic" refers to Asia Minor).

Sustained attention must be given to these and similar writers, however, when discussing the Greeks proper, and especially the Asianic Ionians and Athenians. It is with reference to these Greeks, quite as much as to the earlier peoples, that the present note has been supplied.

See D. G. Hogarth, Ionia and the East (Oxford: The Clarendon Press, I 909), pp. 26-27; Glotz, op. cit., Chap. 4, "Trade", 5, "International Relations", passim., but esp. p. 226; Hall, op. cit., pp. 71, 75, 77; Pendlebury, op. cit., pp. 104, 106, 134, I37.

1 Pendlebury, op. cit., pp. 137, I 58-59; Glotz, op. cit., pp. 353-54. It should be noted, however, that many archeologists think that the quick wheel was invented in Asia. See Pendlebury, op. cit., p. 283.

2 Hall, op. cit., pp. 76-77; Glotz, op. cit., pp. 350-52.

3 Hall, op. cit., pp. 73-74; Kantor, op. cit., passim., but esp. pp. i 8-2 I. The latter monograph, incidently, is an up-to-date (1948) and telling refutation of those who would deny the wide scope and large volume of Minoan trade (see note 2 p. 276).

4 Mosso, op. cit., p. I 24; Glotz, op. cit., pp. I91, 199, 202, 2 1 r.

5 Pendlebury, op. cit., pp. 269, 285; Glotz, op. cit., p. 379.

- Pendlebury; op. cit., pp. 140, I68, 218 ; Myres, Who Were the Greeks?, pp. 280-81.

7 Hall, op. cit., p. 38.

8 Ibid. 
the peoples of the north in general and the Cretans in particular. ${ }^{1}$ The Nile and the Red Sea, with occasional voyages to those regions of Arabia and Africa called Punt, and coastwise trips to Tyre, gave the Egyptians all the seafaring they wanted. In later epochs, when an especially risky voyage was to be undertaken, they simply hired the ever-ready Phoenicians, who eventually became the successors of the Minoans to the trafficking "top-side" of Crete. ${ }^{2}$

But regardless of what happened when the "lustful, lying, but wonderfully wise" Phoenician merchants of whom Homer speaks ${ }^{3}$ took over the sea-routes, there can be little question that for a long time the Minoans dominated the Aegean and much of the eastern Mediterranean, stamped out piracy, exacted from many of the islands tribute and crews for their fleet, and brought with them wherever they settled or set up trading stations a bustling, affluent life hitherto unknown. ${ }^{4}$ As Thucydides put it, following a tradition that both he and Herodotus accorded full confidence:

Minos is the first to whom tradition ascribes the possession of a navy. He made himself master of a great part of what is now termed the Hellenic sea; he conquered the Cyclades, and was the first colonizer of most of them. Lastly, it was he who, from a natural desire to protect his growing revenues, sought, as far as he was able, to clear the sea of pirates. 5

Whether there was ever a master named Minos, or two, or a half-dozen, or any at all (he is here called the Minos) is not to our purpose; ${ }^{6}$ the evidence consistently points to the fact that, throughout later centuries of the periods called Minoan, the Priest-King of Crete, however named, was sovereign over a large part of the Very Green and its islands and shores. To the Greeks, latecomers to the "wet ways", he was the first "thalassocrat" - a word combining Minoan for "sea" and Greek for "ruler"." The Minos, Priest-King of the - kosmos.

How fortunate were the overlords and people of this ordered and orderly society is shown by the contrasting example of their Egyptian 1 Glotz, op. cit., p. 28; see index for numerous refs.; Myres, Who Were the Greeks?, pp. I19-1 34, passim.

2 Richard Hennig, Terrae Incognitae (Leiden: E. J. Brill, 1936-37), Vol. I, Chap. I, Die See-Expedition der ägyptischen Königin Hatscheput nach Punt, PP. 5-II; and Chap. 9, Eine phönizische Umsegelung Afrikas im Auftrag des Pharao Necho, pp. 49-53.

Od. xiv, 286-91; xv, 414-19.

- Herod. i, 171; Thuc. i, 4, 8; Glotz, op. cit., p. 159.

s Thuc. $i, 4$.

- "Minos" was probably a dynastic name. But see Hall, op. cit., p. 18; Myres, Who Were the Greeks? pp. 32 1, 351 ; Taeger, op. cit., p. I1 5 .

? Glotz, op. cit., p. 387 . 
neighbors. In Crete, vicinal isolation balanced vicinal accessibility; the legendary man of bronze, Talos, who ran around the island three times a day, fending off would-be invaders ${ }^{1}$, symbolizes the advantages of a culture that had developed to the point where those who came and went could be closely controlled by an armored force of policemen-soldiers. Just as the "splendid isolation" of highly accessible Britain utterly depends on continued mastery of the environing seas - and today on the ever more doubtful dominance of the all-encompassing air - so did Crete depend on the superiority of its maritime culture. Without that superiority, its accessibility would have been a tremendous handicap; with it, accessibility could at will be turned into isolation. The Egyptians, so fully devoting the resources of their culture to the sacred social monism of the Pharaonic Pyramids, never succeeded in taking advantage of their vicinal position. At the beginning of the Rule of the Just Laws the Wall against the Asiatics was built, and had the rulers of the Middle Kingdom extended its ramparts to the full, they might have warded off the attacks of the Shepherd Kings, riders of the "ass of the mountains" - the horse "whose neck is clothed with thunder". ${ }^{2}$ But the wall was breached and circled, the Egyptians did not take over the horse culture quickly enough, and for over a century they lay prostrate under alien misrule. During this same period, though the continuing raids of "Asiatics" and Indo-Europeans kept the whole Near East in uproar and the "horse-breeding Minyans" descended deep into mainland Greece, Crete managed to keep its vicinal isolation, albeit at the cost of temporarily cutting off relations with Syria, Mesopotamia, and Egypt ${ }^{3}$, and leaving to Trojan and Cycladic traders much profitable Aegean commerce. The balanced position was resolutely maintained.

Nevertheless, the power of the Priest-King was shaken before the Middle Minoan period ended, not by earthly rivals such as those who brought low the Middle Kingdom of Egypt, but by Poseidon, wielder of the dreaded trident. As the Greeks might have put it, Minoan success and happiness in the midst of a world in travail called forth the jealousy of the everwatchful immortals 4 , and in one shattering earthquake the presumptuous were humbled. All over Crete the great catastrophe of 1700 B.C. or thereabouts toppled cities and palaces in wild confusion, and for a time it seemed that overweening men,

1 Appolod. I, ix, 16 et seq., quoted by Janet Ruth Bacon, The Voyage of the Argonauts (London: Methuen and Co., Ltd., I925), p. I7.

2 Becker and Barnes, Struts, pp. 90-91, I I-I 2.

3 Pendlebury, op. cit., pp. I 73-75.

4 Svend Ranulf, The Jealousy of the Gods and Criminal Law at Athens (2 vols.; London: Williams and Norgate, I934), passim. 
smitten to the dust, would never again dare to vie with the gods. But dare they did, even though the first Greeks of the mainland, the Minyans, were steadily becoming more troublesome, and within a quarter of a century rebuilding on a scale more grandiose than ever once more challenged the celestial powers. The speed with which Crete recovered maintained the full continuity of the culture; the successive phases of the Middle Minoan period are closely linked with each other in spite of the violently-flung piles of rubble - some massive blocks were tossed twenty feet - that overlie its glories. Indeed, the era of the recovery not only continues but surpasses all that has gone before; the palaces of Knossos, Phaistos, and Mallia, with Knossos more supreme in its beauty than ever, become so delicately intricate that further development of this type seems beyond the power of any ancient people.

Scarcely more than a century had dimmed the memory of the terrible earthquake when Poseidon struck in full fury again. This time, shortly after 1600 B.C., the disaster in some parts of Crete was perhaps worse, but again the Cretans rallied with amazing speed. The rate of recovery surpassed even the previous triumphant burst, and in a final spurt of brilliant achievement the Middle Minoan period draws to a close and, in smooth transition, the Late Minoan begins. ${ }^{1}$

\section{VII}

At last we have come, beginning with the first quarter of that remote sixteenth century before our era, to what is truly the great age of Crete. Everything that has gone before, in spite of its refinement, vitality, precision, and creative originality, is reduced in retrospect to the rank of merely preparatory labor, to the tentative, preliminary phases of the most splendidly elaborate culture that Crete was ever to see. In Late Minoan times, while vicinal isolation could still be maintained by the legendary Talos in spite of the Priest-King's mainland partnership with the lords of Mycenae, Crete ascended those heights from which, like Euphorion in Faust, it forever fell. If in earlier days the Priest-King's sway was sometimes challenged, in this era he reigned in tranquil supremacy. In the land over which he ruled, gems, pottery, costume, frescoes, architecture, court ceremonial, festivals, and games

1 Taeger, op. cit., pp. I I 5, II7; Pendlebury, op. cit., Pp. 146, I48, I58, 173-75, I80, I84, 195, 216 ; Hall, op. cit., pp. 109-207 passim. These notes cover the two preceding paragraphs. It should be noted that Glotz and Toynbee, to name no others, insist, despite the lack of other than "earthquake" archeological evidence, that the destruction of 1700 B.C. was the result of conquest or revolt. See Glotz, op. cit., pp. 40-4I; Toynbee, op. cit., I, p. 92 ; IV, p. 64 ; V, pp. 236-38. Pendlebury, the cautious archeologist of our frequentlycited and quoted Archeology of Crete, finds definite evidence only of earthquake until I 400 B.C. 
all testify to a degree of widely diffused ease, luxury, and perhaps decadence comparable to that of the fabled Atlantis or the Phaeacia of Homer. The envious blows of Poseidon had been followed only by resplendent warrant for still greater envy. Once the Minoan was a "moonlight culture" reflecting the splendor of the Egyptian sun; now it could beam forth its own piercingly radiant light when Egypt lay in eclipse. ${ }^{1}$

That light was soon dimmed and finally quenched, except for a few feeble glimmers, by pupils who bettered instruction, but before the melancholy tale is told, heed must be given to sides of Minoan life we have hitherto slighted or wholly ignored. Such seeming neglect has been for the purpose of first setting in view the more concrete evidence. Inference from the archeological record is of course inescapable at any point, but in the realms of family structure and kinship, religion, and the like, the amount of speculative inference in proportion to tangible testimony is overwhelmingly large, and must remain so until the Minoan script is deciphered. That great day, let us hope, may not be much longer delayed, but in the interval, we must try to extract as much as we can from the data before us, even though we knowingly run the risk of serious error. "Nothing ventured, nothing have."

Beginning with the realm where the ground is shakiest, family life, it can be said that there is a little evidence indicating that the early Minoans may have clustered in large clans. Forms of houses and tombs seem to show that collective dwelling and burial were practiced at first, and that these were later replaced by smaller household family arrangements. Even if the scanty evidence for collectivism were conclusive, however - and that is far from the case - it still would not show that clan collectivism prevailed. Clans have definite and special structure; they are not just flocks of close kin. Analogies drawn by Glotz and others from what is assumed to be Trojan clan living, moreover, have only the force of analogies. The most that can safely be said, then, is that the early Minoans built a number of phalanstery-like houses and tombs, and some good-sized bechive ossuaries, but that as time went on, others usable only by smaller groupings were constructed, and that this shift may have marked the splitting up of big kinship units. ${ }^{2}$ By the Late Minoan period, the small household family, perhaps composed only of father, mother, and

1 Taeger, op. cit., p. II9; Oswald Spengler, Reden und Aufsätze (München: C. H. Beck'sche Verlagsbuchhandlung, 1937), p. 257; Hogarth, op. cit., p. 26; Hall, op. cit., p. 206.

2 Mosso, op. cit., pp. 103-105; Childe, Dawn of European Civilization, pp. 22-26; Glotz, op. cit., pp. 13 1-46; Pendlebury, op. cit., Pp. 279-80; Hawkes, op. cit., p. 353. 
offspring, seems to have prevailed everywhere in Crete among ordinary folk. The dwellers in the palaces may have followed other patterns, but the palaces give few clues except, as Hawkes points out, for one beehive tomb assignable to the closing phase of Middle Minoan. This, however, may bear witness only to cultural conservatism in disposal of the dead; older forms are often preserved in matters felt to be especially holy. It shows little or nothing about the palace "design for living".

What the palaces do show, very clearly indeed, is that in the "design for living" women enjoyed an unusual amount of consideration, freedom, prestige, family prominence, religious veneration, and perhaps authority. The graphic and plastic arts so generously lavished on the palaces testify to all these matters in multifarious detail; some students of things Minoan have gone so far as to call Crete a woman's world. This stretches things a bit; Ariadne may have been priestess, princess, or even queen, but the Minos was king. If the Minoan legends preserved in Greek literature were to be taken at face value, still the system of mother-kin that seems so obviously present does not mean that there was mother-rule; matrilineage must not be confused with matriarchy. Further, the occasional allusions to living in the house of the mother after marriage do not indicate maternal domination; matrilocal dwelling does not in and of itself constitute matriarchy. We may suspect that often mother knew best, but father may have had a decisive word to say once in a while, even though the mother's brother was the customarily dominant male, and even though every male wore "the kilt instead o' the trews".

Granting all this, it yet remains true that the Minoans strikingly contrast with the Athenians, for instance, in the place accorded to woman. Far from being confined to the inner quarters of the household, the ladies of Knossos promenaded as they saw fit, and their reputation for generosity in the bestowal of their charms, even when legitimate wives, was matter for scandal among the many Athenians who interested themselves in Minoan legend. The betaira or "companion", the concubine, and the common prostitute the Athenian $\mathrm{knew}$, tolerated, and on occasion approved, but the wife who indulged in so much as a flirtatious glance was an unworthy creature. Not only did the Minoan woman have much leeway as wife, but also when

1 J. J. Bachofen, Gesammelte Werke, Vol. II-III, Das Mutterrecht (Basel: B. Schwabe and Co., 1948), passim., especially part 2 of Karl Meuli's Nachwort and those sections of the original that it illuminates and corrects; Robert Briffault, The Mothers (New York: Macmillan Co., I 927), I, pp. 388-414; III, pp. I I 8-84 (to be used with great caution, but abounds in data and has a remarkably fine bibliography); George Thomson, Studies in Ancient Greek Society: The Prehistoric Aegean (London: Lawrence and Wishart, I949), pp. 58-86, 149-202 (doctrinaire Marxist; extreme). Cf. the cautious statements of H. F. Rose, Primitive Culture in Greece (London: Methuen and Co., Ltd., 1925), pp. 26, 167-68. 
unmarried she seems to have been little limited; "virgin-born" children suffered under no stigma. Motherhood as such was held in great honor, and the influence exercised over sons, for example, was strong and tenacious. Indeed, the mighty Mother Goddess of Crete is often depicted with her son filling the post of a kind of adjutant god, or appearing simply as the twice-born son Zeus, the divine child. 1

With this hint as to the eminence of woman not only in family affairs but also in things religious, we are not unduly startled by other goddesses or other aspects of the great Goddess: Britomartis the Rushing Maiden, Diktynna the Mistress of Animals, Eileithyia the Nature Queen, nor by their holy and hieratic female retinues so often indistinguishable from goddesses. The arm-brandishing evocations and invocations, the solemn, chorusing processionals, the ecstatic dancing, the genuflecting before the altars, the holy pillars, and the hallowed trees - all these and many more religious acts are carried out by women in whom goddess and priestess are strangely intermingled. Checking our own impressions with those of others, agreement with Wilamowitz ensues at once: "It has been widely remarked that male gods almost entirely recede into the background in Crete." 2 Exceptions are the twice-born Zeus just noted, and the beardless youth - son, consort, or both - so often appearing as attendant of the Mother Goddess or Priestess. ${ }^{3}$ Perhaps these are not really exceptions, for neither is a principal in the drama of Minoan religion; their roles are minor. Never, for example, do they or other males lay hands on the holy double axe, embrace the horns of consecration, let the blessed snakes writhe about their necks and arms, or drain from the bull at the altar the blood of sacrifice. Yet we know that the Minos was PriestKing. How can we guess the riddle?

Starting as far back as we can, we remember that in earliest Crete, as elsewhere in many countries from the Euphrates to the Adriatic and beyond, the figurine of the female with tremendous breasts and buttocks, deeply marked navel, and protruding triangular mount served as symbol of goddess and priestess alike - fertility incarnate. ${ }^{4}$

1 Taeger, op. cit., pp. I 20-2 I ; Martin P. Nilsson, A History of Greek Religion, trans. by F. J.Fielden (Oxford: The Clarendon Press, 1925), pp. 25-34; Pendlebury, op. cit., p. 273.

2 Wilamowitz, op. cit., p. I 24. Cf. Taeger, op. cit., I, p. I 2 I.

3 Hogarth, op. cit., says that there was in this a "Dual Monotheism", or, as we might put it, a Binity rather than a Trinity. Nilsson leaves open the possibility of other gods; see his Minoan-Mycenaean Religion and Its Survival in Greek Religion, pp. 334 et seq. For the fact that goddess and priestess are often hard to distinguish, see Nilsson, op. cit., p. 280; Glotz, op. cit., p. 265 ; Schuchhart, op. cit., p. 172. For discussion of the Mother-Goddess, see Nilsson, op. cit. pp. 389-405, esp. 394-95.

4 Mosso, op.cit., pp. I 3 I, I 48-r 70; Childe, Dawn of European Civilization, pp. 17-18; Hall, op. cit., p. 29 ; Evans, op. cit., I, fig. I 2 ; Pendlebury, op. cit., pp. 38 -39; Glotz, op. cit., p. 243. 
In the Cretan cave-dwellings that later became shrines and temples, birthplaces of "the divine child", weird rites of many kinds were devoutly practiced during the long centuries of Neolithic times. ${ }^{1}$

Playing essential parts were all sorts of animals; they appear in such profusion that Egyptian zoölatry, Babylonian and Assyrian man-bull and man-bird hybrids, Hebraic golden calves, and many other analogies come to mind. ${ }^{2}$ It is highly probable that these are more than analogies; in the dim past of the Southeast-European, North African, and Near Eastern regions, with their many land-bridges and interconnecting routes now beneath the waves or broken and blocked by upheaval and silting, there may well have been much wandering of Afrasian peoples ${ }^{3}$ and their practices to and fro. That past is so remote, however, that in Crete as we encounter it only the island stepping-stones, with their hop-skip-and-jump navigation, afforded the necessary avenues, and as we have seen, Minoan culture had remarkable functional continuity and amalgamative power. We must therefore grant much room for relatively independent development in spite of the diffusion that undeniably must have gone on early and late. Moreover, although animals, plants, and lifeless things and happenings in the realm of earth, sky, and sea can be assigned symbolic functions only within the meaningful frame of a given culture and society, it is also true that some more often serve as symbols, whatever the culture and society, than do others. Man is not a disembodied spirit; 4 culture patterns must somehow fit a hairless, two-legged, talking mammal. The range of alternative patterns is vast indeed, but they are still man's patterns. The non-human symbols he selects will not be devoid of possible reference to his own powers and his peculiar kinds of helplessness. ${ }^{5}$

But here controversy or even polemics begin to appear; let us therefore merely say that what follows can be regarded as special emphasis only, and that no denial of diffusion, functional integration,

1 Nilsson, A History of Greek Religion, p. 12; Revue de l'histoire des religions (Paris: Enst Leroux, ed., IgI I), Vol. LXIV, Part 2, pp. 277 et seq.

2 Pendlebury, op. cit., Pp. 274-75; Hall, op. cit., pp. 16, 133, 278-79; Encyclopaedia of Religion and Ethics, ed. by James Hastings (New York: Charles Scribner's Sons, I 908-22), arts. "Theriomorphism", "Zoölatry", etc.

3 Sir John H. Marshall, Mohenjo-Dato and the Indus Civiliszation(London: A. Probsthain, I93 I), I, pp. 93 et seq.

4 See Becker, Man in Reciprocity (New York: Frederick A. Praeger, 1956), Chap. VI, "Human Nature Becomes Human", pp. 79-95.

5 Cf. A. L. Kroeber, Configurations of Culture Growth (Berkeley: University of California Press, 1944), pp. 16-27, 838-46; R. R. Marett, Head, Heart and Hands in Human Evolution (London: Hutchinson, 1935), pp. I50-23x; William Howells, The Heathen: Primitive Man and His Religions (New York: Doubleday and Co., 1948), pp. I 1-24, 283-93 et passim. 
and other matters of technical interest primarily at this point, is intended or implied. In particular, there is no espousal of "naturism". 1

In Crete, from earliest to latest Minoan times, the snake everywhere wriggles its way into religious affairs. It seems to be the symbol of male penetration or even to be regarded as the active agent of impregnation -i.e., the snake is not merely like the phallus but is the phallus, and vice versa. The holy marriage of the priestess was a closely guarded mystery, but although in later times other man-animals lurk about the inner sanctuary of consummation, or alone await the bride, the snake is never wholly banished. Perhaps this was because of the role of "the glider in the narrow places" as patron and protector of the crannied cavern and later of the house and palace; skill to descend into remote recesses showed its affinity with the powers beneath and within the earth, with things chthonian and dark. So persistent was its task as guadrian of man's abode that in some house-shrines the "snake-tubes" seem to have no assignable function other than as entries and exits for the indispensable defender. ${ }^{2}$ Beyond this, the silent sentinel acted as emissary to and from the feared and cherished dead, who at first were tucked away in the far corners of the cave-shelters themselves, later in their own rocktombs, later still in charnel houses and ossuaries, and finally in honey-filled urns ${ }^{3}$ and in clay coffins with openings that served either for drainage of the fluids of decay, for the visits of the slippery messenger, or both. ${ }^{4}$ Phallic symbol, protector of the dwelling, familiar of the departed - the holy snake.

Of almost equal prominence, however, were the boar, buck, ram, and bull, considered together - although by Middle Minoan times the bull was overwhelmingly more important than the others. Here, in the male animal of vigor and virility, is a source of awesomely wild strength overmatching man's; the splendid, snorting rage of the beast evokes terror and daring alike. To subdue him unaided is to acquire his might; ${ }^{5}$ to trick him is to show that feeble man is still, through his mind, king of creation; to vault over his goring horns is

1 By "naturism" is meant that body of theory according to which the "sheer senseimpressions" of sun, sky, animals, and the like on "man's spirit" directly engender the attitude of worship and the corresponding sun-gods, sky-gods, etc. Max Müller, for an earlier period, is the most outstanding representative. The incompatibility of such a theory with our present knowledge of comparative religion should be obvious.

2 Pendlebury, op. cit., p. 274.

3 Axel W. Persson, The Religion of Greece in Prehistoric Times (Berkeley: University of California Press, 1942), pp. 9-19.

4 Nilsson, Minoan-Mycenaean Religion and its Survival in Greek Religion, Pp. 90, 3 I6-r9; Hall, op. cit., p. 190 and refs. given there.

5 Breaking his neck by "bulldogging" was the climactic scene of the Minoan corrida; Persson, op. cit., fig. 23, pp. 96-97. 
to rise ecstatically above the threat of death. ${ }^{1}$ And here, in the very epitome of maleness, is a source of the hot jet of potency, gushing with an abundance and frequency that evokes envy, emulation, and quivering desire among the human watchers. ${ }^{2}$ Europa is ravished by the divine bull who carries her over the sea to Crete, and she bears him Minos and Rhadamanthus. Pasiphaë, wife of Minos, lets the cunning artificer Daedalus contrive for her the animal guise that permits her cow-like union with the bull of the palace sanctuary, and the man-bull, the Minotaur, is born to roam through the terror-filled Labyrinth. ${ }^{3}$ Legends, but legends that shadow forth a dim reality of some kind.4 Much less dim, and in some respects quite clear, is the reality of the bull sacrifice. In a vivid Late Minoan coffin painting ${ }^{5}$ is shown the bare-bosomed priestess who, with animal-skin skirt dangling the tail, fronts the altar. Her hands reach out toward the laver and ewer that rest upon it, and she gazes fixedly at the holy double axe, topped by a perching bird, standing upright before her. With great round eyes staring directly toward the beholder lies trussed on the table behind the priestess a huge bull. Arms uplifted and fingers outstretched, to the rhythm of the flute, come pacing the women of the holy procession, and streaking down into the ready vessel on the floor run the red gouts of the bull's blood. There flows the essence of life itself, making a sweet savor in the nostrils of the unseen powers. Apart from and yet perhaps allied to the blood sacrifice were the double horns of conse-

1 Evans, op. cit., III, pp. 203 et seq.

2 The bull often possesses a disproportionately large phallus, i.e., is ithyphallic; Persson, op. cit., pp. 93-94.

3 Ibid. pp. I 3 r-35; see also relevant articles in M. Cary et al., ed., The Oxford Classical Dictionary (Oxford: The Clarendon Press, 1953).

4 Nilsson has asserted that there is no evidence for a "bull-cult", i.e., for worship of the bull, or anuthing similar. The bull was merely an animal of sacrifice and for the "sport" of the bull-ring. Mylonas, among others, has followed him in this. In the light of the evidence and what equally cautious scholars have pointed out, this negative judgment seems impossible to sustain. Cf. C. N. Deedes, The Labyrinth S. H. Hooke, ed. (London: S.P.C.K., 1935), p. 28; see also Jane Harrison, Themis: A Study of the Social Origins of Greek Religion (2d. ed. rev.; Cambridge: The University Press, 1927), p. 169; L. Malten, Der Stier in Kult und mythischem Bild, Jahrbuch des Deutschen Archäologischen Instituts (Berlin and Leipzig: Walter De Gruyter, 1929), Vol. XLIII (I 928), pp. 9o et seq; Persson, op. cit., pp. 93-98. The present writer agrees with Malten, Persson, and others; although Harrison was too speculative, Nillsson seems much too conservative. But see Nilsson, Minoan-Mycenaean Religion and its Survival in Greek Religion, pp. 373-81 ; Pendlebury, op. cit., Pp. 274-75; G. E. Mylonas, Athens and Minoan Crete, in Athenian Studies Presented to William S. Ferguson, ed. by C. W. Blegen, Harvard Studies in Classical Philology, suppl. Vol. I (Cambridge: Harvard University Press, 1940), p. 33 .

s Nilsson, op. cit., pp. 229-30; Mosso, op. cit., pp. I 94-97; Monumenti Antichi, Accademia Nazionale dei Lincei (Milano: Ulrico Hoepli, 1908), XIX, plates I and 2; Pendlebury; op. cit., p. 249. 
cration cresting in long lines of stone the edges of the palace roofs, the clay containers in the likeness of the bull's head stoppered by the handle of the double axe, and the magnificent bull's-head relief in painted stucco on the royal dwelling at Knossos. ${ }^{1}$ Symbol of raw muscular strength, epitome of frenzied rage successfully defied, exemplar of sexual vigor, and source of copious life-offering to the veiled forces surpassing man - the holy bull.

Virtually as evident as "the footless and the four-footed" in Minoan religion were the winged creatures. ${ }^{2}$ Thinking of the doves of Aphrodite and the eagle of Zeus that bore aloft the beautiful Cretan boy Ganymede, some scholars have tried to limit stress on the birds revered by the Minoans to these two kinds, but the frescoes, painted pottery, and small stone and metal engravings give no warrant for such narrow scope. Waterfowl, ravens, partridges, cuckoos, and owls also received attention and, to say the least, regard. Any voyager of the air whatsoever seems to have called forth "the idea of the holy"; it almost seems as though sheer "birdliness" was enough for the Minoan. Darting down with heavenly bane or blessing the quick-winged creatures come to rest on the doomed victim, the double axe, the head of the priestess, or the limbs of the holy trees. They are familiars, twittering mysteries to those who know their speech, and they are bestowers and guardians of the shell filled with the warm jelly from which, for the Orphics, the world was made. ${ }^{3}$ And did not Leda, coupling with the divine swan, give forth the egg out of which the peerless Helen came? Late though the story is, it has been traced to its source in Minoan legend, the legend of the holy bird. ${ }^{4}$

Receiving too their meed of homage, and occurring both within and outside the early rocky shelters and the later abodes of man's rather than nature's building, were the holy stones and pillars. Some of them ominously fell from the lowering, flashing sky. Others threateningly shook and toppled when the solid ground quivered. Still others sturdily bore up the cracking, rending roofs of the shrine-dwellings. Others again uncannily mimicked the bodily parts or the very shape entire of man or beast - navel-stones, slumbering giants, frowning

1 Thassilo von Sheffer, Die Kultur der Griechen (Vienna: Phaidon, 1935), pl. 5; Glotz, op. cit., pp. 233-34; fig. 49, pp. 272-73; Pendlebury, op. cit., pp. 157, 239. There is little or no evidence, however, to show that in Crete an axe was used, as in Attica, to kill the holy bull. For the double axe in general, see Mosso, op. cit., Pp. 132-47, and Nilsson, Minoan-Mycenaean Religion and its Survival in Greek Religion, pp. x94-235.

2 W. K. C. Guthrie, Orpheus and Greek Religion (London: Methuen and Co., Ltd., 1935), pp. 92-96; Nilsson, A History of Greek Religion, pp. 2 1 5-1 6.

${ }^{3}$ Nilsson, Minoan-Mycenaean Religion and its Survival in Greek Religion, chap. Io,

"Bird Epiphanies of the Gods".

4 Oxford Classical Dictionary, "Leda". 
faces of the gods, horned heads leveled for the onrush, paired breasts, the male member. On occasion any of these, and yet others possessing but the one tremendously important quality of being there, marked the place where the tremor of ecstasy, thrill of awe, chill of dread, surge of power, or freak of luck announced the presence of that which passes the might of the merely human. The Greek baitylos, the Hebrew betb-el, the holy stone - sometimes, as man-made pillar, grouped in a triad - this, however named by the Cretans, was a persisting religious force from the Neolithic to the late Minoan. ${ }^{1}$

Figuring also in the faith of the Cretans were trees; Evans, in fact, considers "the tree and pillar cult" to have been the very core of the religion. Certainly the tall, swaying things that so strangely put forth bud, flower, and fruit, each according to its kind and in due season, have among many peoples symbolized fertility and evoked adoration. They gently rustle wisdom with the passing breezes or shriek and toss their clutching hands wildly as the tempests roar through them. As the sun goes through its yearly round they mysteriously pulse and spurt and waste away to the flow and ebb of lifegiving sap. When they tower too high they are stricken by the flashing envy of the mighty ones they have the presumption to rival, and their burning bodies long ago gave the gift of fire to man. In their branches nest the birds that fit and dart and soar, divine messengers triumphing over Icarus. Their long beams, magical in strength and resilience, make possible the journeys of the oarsmen and sailors who bring home the tunny, the squid, the crimsoning murex, the sponge, and the treasured trade-goods, booty, gifts, and tribute of faraway shores. Whatever the source from which their devotion diffused, well might the Minoans continue to bow down before the holy tree. ${ }^{2}$

But everywhere in Cretan life, as the integrating religious center, as a cistern filled from many springs and yet as herself a fountain, appears the female-mother-priestess-goddess. She it is who flows and ebbs with the waxing and waning of the moon, giving forth the issue of blood, fluid of mystery. From between her outspread thighs are vouchsafed both breathless joy and the wail of the newly-born. Out of her bared, turgid bosom pour the juices of deliverance from helpless, suckling hunger. To her fly the birds, for her bellows the

1 Rose, op. cit., p. ro; Sir Arthur Evans, The Earlier Religion of Greece in the Light of Cretan Discoveries (London: Macmillan and Co., Ltd., I931), p. 13; Nilsson, MinoanMycenaean Religion and its Survival in Greek Thought, pp. 236-61, esp. pp. 255-59.

2 See all of chap. 2 of Persson, op. cit., Minoan-Mycenaean Signet Rings and the Vegetation Cycle and all of chap. viii of Nilsson, Minoan-Mycenaean Religion and its Survival in Greek Thought, 'The Tree Cult. 
bull, under her touch the trees yield their gifts, and before her uprear the pillars. What remains as the function of the Priest-King in the realm of the holy woman?

\section{I I I}

The function of the Minos as reflected in the Greek legends remained. The Cretan kosmos had to be made and kept a kosmos by establishing and preserving the balance of isolation and accessibility. Even if it were true that Minoan woman completely controlled the Church - and, as will be shown, this sweeping assumption cannot be made - it would not follow that the State could be left out of account. After all, Pope Joan herself had recourse to the secular arm. The question may well be raised, however, as to the role of woman in the peaceful social controls of the ordered and orderly Minoan society; perhaps the State, in this somewhat improperly extended sense, owed much to the Cretan female.

Seeking the answer in analogy, for other evidence is lacking, it can be said that the early Minoans perhaps in some ways resembled the peaceful Zuñi of the southwestern United States. These phalanstery or pueblo dwellers likewise have a matrilineal clan system, and the son-in-law also goes to live in the apartment of his wife's mother after marriage. The Zuñi culture, too, has great continuity, having resisted the corroding acids of contact with the Spanish and Americans much better than the other cultures of the region. If we could be sure that the pacific character of Zuñi society resulted from these factors alone, then a plausible case might be made for similar factors in peaceful Minoan life. We can by no means be sure, but let that pass. ${ }^{1}$

Instead, let us turn to another analogy, the Iroquois. Here we have a people with a matrilineal clan system, dwelling in "long houses" accommodating from ten to twenty individual family units, and granting a degree of prominence and influence to women that, although falling short of matriarchy, permitted them to nominate and impeach chiefs, who were male. Were they a well-organized people? The best-organized, if political integration is any criterion, of all Indians north of Mexico. Were they a peaceful people? General Walker said this: "The career of the Iroquois was simply terrific. They were the scourge of God upon the aborigines of the continent." 2 Alas for analogy!

The most that can be assumed, then, is that the Minoan kinship system as such may not have hampered the establishment of a kosmos,

1 Ruth Benedict, Patterns of Culture (Boston: Houghton Mifflin Co., I934), chap. IV, The Pueblos of New Mexico.

2 F. A. Walker, The Indian Question, North American Review, Vol. CXVI, No. 239 (1873), p. 370, note. 
and may even have aided it strongly - but only in conjunction with other equally necessary factors. And what of the sufficient factor?

Postponing the effort to deal with this last question, let us turn to the apparently high status of woman in Minoan life in the search for keys to the kosmos. In and of itself, the matrilineal clan cannot account for this status, for we know of many peoples among whom mother-kin is linked with abasement of woman, and of many others among whom father-kin and elevation of woman go together. Women are somewhat less likely to be abused when residence is matrilocal, but residence is another matter, not inseparably bound up with the kinship system; there may be patrilocal dwelling and matrilineal descent, as among the Trobrianders. The reverse - i.e., matrilocal dwelling and patrilineal descent - is rarely found, yet it does occur, and under it the status of woman varies from high to low. ${ }^{1}$ Leaving issues like this aside, however, is it likely that the consideration and even privilege accorded Minoan women account for the apparently pacific character, within itself, of the Minoan kosmos? Again, only in conjunction with other necessary factors. Among the Spartiates women notoriously ran their husband's non-military affairs, illicitly but frequently had children by Serfs and Satellites ${ }^{2}$, and in general did pretty much as they pleased, but Spartan society was built on the practice of the utmost ferocity against the lower orders. The internal peace that existed was that of a beleaguered garrison. Again analogy fails us.

The influential Minoan woman, then, may have been able to alleviate tensions arising within Minoan society, but her social power and prestige alone could not generate all the conditions needed for a kosmos of the kind we seem to have encountered in Crete.

Returning to the part played by woman in the Minoan religion, can it be that we have at last singled out the sufficient factor? Let us reflect. Her part was tremendously important, no doubt whatever of that - but how did it fit into the total context? That context, particularly as regards what we shall continue to call the Minoan Church ${ }^{3}$, is not yet fully before us. We register this fact, and proceed.

Did the priestess so fully overawe those who might otherwise have been active rebels that no open dissension ever arose? Given the majestic, fully-credited symbols of her power, from the cross with a handle, the crux ansata, to the conch-shell that she blew to evoke the

1 Robert H. Lowie, An Introduction to Cultural Anthropology (4th ed.; New York: Rinehart and Co., Inc., 1946), pp. 241-43, 255-66; E. A. Hoebel, Man in the Primitive World (1st ed.; New York: McGraw-Hill Book Co., I949), pp. 22 I-26, 260-73.

2 Here the writer introduces his terms for the helots and perioikoi.

3 The term is not used in quite the same sense as it occurs in Toynbee, op. cit., passim. The difference is not significant, however, for our own analysis is much less daring than Toynbee's, and the term has little weight to carry. 
divinity ${ }^{1}$, this is not an impossibility. Did she, as symbolized in the ever-present holy knot ${ }^{2}$ from the example of which, perhaps, one of the possible etymologies of religion - religare, to bind fast 3 - was drawn, bind men to her by ties of reverence and filial affection? So firmly that the social order in which she was an absolutely essential figure was never even called in question? Such utter loyalty doubtless could be evoked; other holy knots, figuratively speaking, have tied believers so effectively that they have sacrificially died without ever realizing that they were bound, much less that the knot could be severed. In other words, was the favored model of personality brought to the notice of and prevailingly elicited among the Minoans by their mother-goddess-priestess religion of a kind making for a high degree of harmony in the affairs of daily life? By no means unlikely; we have some warrant for assuming that the Jesuit state of Paraguay largely owed its career, long and peaceful for its day, not only to its efficient army but also to the way in which its formerly ferocious Guarani Indian members responded to the training in submissiveness imparted to them by their mentors. ${ }^{4}$ And was this religious factor in personality and culture the one that lent to all the others their full importance in the kosmos equation? We are back where we started.

A way out of the impasse may lie in a more complete picture of the context that, as we noted, is not yet fully before us. Waiving the point that "fully" brings up manifold problems of method, and hence restricting it to the scope of present purpose, let us try to specify the place of woman in the Minoan Church.

It has already been shown that male deities are rare except as appendages, so to speak, of the mother-goddess. True, several engravings have been found in which a male, much smaller than the priestess or goddess, is descending toward her from the upper air with his hair streaming upward, and this has been called an epiphany or manifestation of the supreme god. ${ }^{5}$ Quite as readily, however, it could be interpreted as the arrival of the subordinate son or consort,

1 Glotz, op. cit., pp. 227, 233, 239, 241, 255-56, 269, 399; Hall, op. cit., p. 281. For the role of the priestess-goddess in relation to the palladium or holy shield, see Nilsson, Minoan-Mycenaean Religion and its Survival in Greek Religion, pp. 406-r 2.

2 Hall, op. cit., p. 280; Glotz, op. cit., pp. 230, 234, 274; Persson, op. cit., pp. 92-93.

${ }^{3}$ Nilsson, Minoan-Mycenaean Religion and its Survival in Greek Religion, pp. 162-64;

Becker and Barnes, Struts, p. 37.

4 Anon., A Compleat History of Spanish America, etc., with an Appendix in Which is Comprehended an Exact Description of Paraguay, Dedicated to Thomas Winnington, Esq., trans. from a French account of 1708 (London: Stagg and Browne, 1742), pp. 320-30. 5 Hall, op. cit., pp. 275-76; Pendlebury, op. cit., p. 273; Persson, op. cit., pp. 8, 19, 36, $47,49,64,88$, I5s, see also plates I and Is; Glotz, op. cit., p. 236. 
for all the other evidence presents us with "auxiliary" males only. Particularly is this true in ceremonial, liturgical, and ritual scenes; males there figure merely as acolytes and attendants of the priestess. Persson has discovered what he thinks to be a picture of three beardless males in the garb of priestesses, one of them carrying a knife, and concludes that these are like the galli of the Great Mother-Goddess of Asia Minor - that is to say, self-emasculated eunuchs. ${ }^{1}$ The principle of paternity seems far to seek.

Everywhere in Crete the priestess-goddess, following the Neolithic pattern, is shown with prominent and sometimes extraordinarily distended breasts, and in a few instances her hands press upon them as though she were giving visible witness of her power to supply the white fluid of motherhood. ${ }^{2}$ Whence came the maternity of the priestess, whence the divine child? Who took the part of the holy swan, eagle, bull, snake, or phallic pillar-stone? Who was the male in the holy marriage?

In the attempt to answer these questions, the element of inference - indeed, of imagination - must be even greater than heretofore. Nevertheless, there is some tangible evidence. All over Crete, when the rock-shelters are abandoned except as centers of occasional shrine pilgrimage, many of the larger houses that replace them incorporate shrine-rooms. ${ }^{3}$ Further, in the various palaces that precede or become ancillary to the great Palace of the Minos, or both, special quarters devoted to the performance of religious ceremonies are thoroughly integrated with the rest of the structure. ${ }^{4}$ Moreover, the Palace of the Minos itself not only has extensive quarters of this kind, but is also crested around the roof-edges with long rows of the horns of consecration, symbols of the holy bull. In its entirety, then, it is a holy building ${ }^{5}$, seat of the lord spiritual and temporal, a grandiose token of the kingly sway of divinity and the divine right of kings. Without hesitation the Minos could say "I am Pope; I am Emperor". He was literally the Priest-King. His dwelling fused the attributes of cathedral and royal residence; it was a merger of St. Paul's and Windsor. And the great priestess who was also in some strange way the MotherGoddess lived therein, worshipped and worshipping before fire-altars

1 Persson, op. cit., pp. 56-58, 90, I I0-1 r ; Hall, op. cit., pp. 281-82 ; Sir William M. Ramsay, Asianic Elements in Greek Civilisation, the Gifford Lectures in the University of Edinburgh, 1915-16(London: J. Murray, 1927), p. 174 .

2 Glotz, op. cit., pp. 243, 244, 247.

3 Nilsson, Minoan-Mycenaean Religion and its Survival in Greek Religion, pp. 77, I16;

Pendlebury, op. cit., Pp. 39, 102, 130, 148, 239, 255 .

4 Ibid., pp. 272-73; Schuchhardt, op. cit., pp. 68-70.

5 Nilsson, Minoan-Mycenaean Religion and its Survival in Greek Religion, pp. 184-86; Glotz, op. cit., pp. 253-54. 
and libation altars sanctified by the ever-present labrys, the double axe. Can it be that here, in the intricate consecrated corridors of the Palace of Knossos, was the Labyrinth of the Minotaur? Was the Minos himself the Man-Bull? ${ }^{1}$ Does the lurid story of Pasiphaë's lustful, cowdisguised mating with the holy animal hint at what really happened in the relations of priestess and king ? ${ }^{2}$ As one ordinarily sober scholar puts it:

"...the Minotaur! Dare we believe that he wore the mask of a bull? Such imaginings may not be suitable to archaeology but, with this possibility in mind, I defy anyone to enter the Throne Room without a strange thrill." 3

Roaming beyond Crete to a land where the Minoan heritage was large, we cannot help further imaginings: Athena, the Virgin Goddess, defender of the rocky stronghold of the Acropolis, had as her specially holy shrine the Erechtheum. "Virgin" here means only unmarried, "defender" means the holder of the holy shield so often appearing among the appurtenances of the Cretan Mother-Goddess; Erichthonios, born of earth-spilled seed of Hephaestus, is represented as half-man, half-snake; and in Attic myth this snake-man is virtually indistinguishable from Erechtheus, legendary king of earliest Athens. ${ }^{4}$ But we roam too far afield; the connections of Crete and Attica do not here concern us. Nevertheless, the analogy is of interest at this point: the uncanny combination of man-animal, king, palace shrine, and priestess-goddess also appears outside of Crete - and that is all. Analogy at this point has not failed us, but perhaps because it is more than analogy.

Our brief sketch of the context of woman's role in Minoan religion would seem to show that her influence was probably of great importance in establishing social control, but that this could be exercised only in a Church inseparably united with a State. Local priestesses had to be subordinate to the great Palace Priestess if rival worships were not to create turmoil. A kosmos, even a primarily religious kosmos, extending over all of Crete could not be established without a centralizing political power, an administration, and an accompanying bureaucracy. Further, even if the cultural compulsives of the MotherGoddess succeeded in allaying strife among her children, or in pre-

1 Milsson, Minoan-Mycenaean Religion and its Survival in Greek Religion, pp. 184-86; Glotz, op. cit., pp. 253-54.

2 Thomson, op. cit., pp. 283-85, 383; A. B. Cook, Zeus (Cambridge: The University Press, I91 4-40), I, pp. 464-96.

3 Pendlebury, op. cit., p. 23 ; Cook, op. cit., I, pp. 466 et seq.; III, passim.

4 Oxford Classical Dictionary, articles Athena, Erechtheus, Erechthonios; Nilsson, History of Greek Religion, pp. 25-27; Thomson, op. cit., pp. 26r-62; Nilsson, MinoanMycenaean Religion and its Survival in Greek Religion, pp. 7, 491-502. 
venting it from appearing at all, this could occur only in domestic affairs. Foreign affairs were another matter. Freebooters from overseas would certainly have been little deterred by the spectacle of hordes of half-naked, dancing, singing women, even though the writhing serpents in their hands might call forth wonderment or even dread. Hence it must be said that although the part played by the Minos or his agent in the holy marriage may well have remained esoteric, therefore ostensibly leaving to the woman's religion the major public role in domestic social control, and although only a bare minimum of force had to be added to the consent granted by a people not ordinarily inclined to rebellion, the Minoan Church was not the sufficient factor in the kosmos. The State, at the very least where foreign affairs were concerned, was that factor. The Priest had to be King as well. Otherwise and more technically put, the Minoan State Church or "ecclesia", staffed by women, had a supreme male pontiff possessing a monopoly of the legitimate use of physical force, and to this monopoly, as sufficient factor among the many necessary factors, the Cretan kosmos must be attributed. ${ }^{1}$

But all things human change. True, not only did Crete reach during Late Minoan times what for the ancient world was the pinnacle of perfection, but in addition the maritime might that had been accumulating from the latter part of the Middle Minoan period onward was to come to a climax. The Church-State emerged, in a brief burst of glory, as a genuine world power ${ }^{2}$, dominating in senior-member partnership with Mycenae not only the Aegean but the entire northeastern Mediterranean, by peaceful trade when possible, by naval strength when necessary. Vicinally accessible to a remarkable degree, and at the same time vicinally isolated behind the shielding fleet of the Priest-King, the marvelous island could be challenged for supremacy only by rival seafarers such as the Minyans and Achaeans, and for a long time such rivals had been dispersed, dissuaded, or taken into junior partnership. The thalassocracy of Minos seemed destined, like Britannia, forever to rule the waves. Still, even in a kosmos apparently free from an internal proletariat ${ }^{3}$ foresight can prove to be vain;

1 Here we have returned to a more workable definition of the State; see Becker and Barnes, STruts, pp. 27-30, also see index.

For the astonishingly large amount of palace space assigned to the bureaucracy, see Evans, The Palace of Minos, I, fig. I 2 et passim.

For what may be a picture of the Priest-King himself, in his kingly role primarily, see the famous Knossos wall-relief, variously called The Prince with the Feathered Crown (Schuchhardt, op. cit., p. 70), Youth among the Lilies (Scheffer, op. cit., p. II), and Evans, The Palace of Minos, II, part 2, frontispiece, pl. 14.

2 Pendlebury, op. cit., pp. 286-88.

3 Toynbee, op. cit., passim. (use index). 
first appeared a successful challenge to trading supremacy ${ }^{1}$, and finally came a political catastrophe that Poseidon, with all his earthshaking, had proved powerless to bring about. Rising ever more regally from the leveling strokes of the trident, Crete collapsed at last before the onrush of Greek warriors who three centuries before their victorious assault had known little or nothing of the paths of the sea. ${ }^{2}$ And in the last decade of the fifteenth century on a spring day, when a strong south wind was blowing that carried the flames of the burning beams almost horizontally northwards, Knossos fell. ${ }^{3}$

Are these the men of iron, with "their righteousness in their fists"? No, the conquerors of Knossos are Achaeans or even their predecessors, the "horse-taming Minyans", but as time showed, their triumph over the Priest-King was hollow. That, however, is another story.

1 Kantor, op. cit., pp. 49-55, esp. pp. 54-55.

2 Glotz, op. cit., pp. 47-48; Pendlebury, op. cit., pp. 228-30; Eyre, op. cit., pp. 162-63; Childe, Dawn of European History, p. 27.

3 Pendlebury, op. cit., p. 23 ; ; cf. the vivid description in Glotz, op. cit., p. 48.

Since completing the present article, the writer has become familiar with the work of Robert Graves as embodied in The Greek Myths, volumes I and II (Baltimore, Maryland: Penguin Books, Inc., 1955). Although Graves' speculations on the scanty available evidence are daring.in the extreme, they are highly suggestive, and would be taken account of both in the body of the article and these notes if present opportunity permitted. The writer feels, however, that in view of the fact that The Greek Myths has just appeared, he must familiarize himself with the critical reaction to Graves' extraordinarily stimulating but venturesome interpretations. Moreover, it also seems necessary to become familiar with Graves' other writings, notably The White Goddess, which the writer has not yet had the opportunity of reading.

At this point it is perhaps enough to say that the hesitant conclusions of the present article are in some instances paralleled by the much more sweeping and confident assertions found in The Greek Myths. Such parallels are in no way viewed as corroborations of the present writer's conclusions, for they have been arrived at by routes covering much different ground. Nevertheless, some of these parallels may lead readers to give the attention to Graves' work that it undeniably deserves, whatever may prove to be the outcome of critical evaluation. 